\title{
Sex Chromatin の研究
}

札幌医科大学泌尿器科教室 正 田 政 博*
(主任 ${ }^{*}$ 高井修道教授)

\section{STUDIES ON SEX CHROMATIN}

\author{
Masahiro Hikita \\ Department of Urology, Sapporo Medical College \\ (Chief: Prof. S. Takai)
}

1. The staining method of sex chromatin must be simplified and at the same time the picture must be clear and readily observable in order to be accepted as a routine clinical examination, and further it becomes necessary to set a standard or criterion.

i) In the present work a comparative study was made on cases with normal and abnormal sex chromosome constitution using the following methods: Guard's staining method, Feulgen staining method, acetoorcein staining method, Giemsa staining method and hematoxylin and eosin staining method. As a result it was shown that the aceto-orcein staining method satisfied the above described conditions.

ii) Studies were made on 100 cases, each of normal male and female subjects, and on 18 cases of abnormalities of the sex chromosome constitution, with respect to the frequency of appearance of different heterochromatic bodies in the nucleus. As a result the author is now of the opinion that sex chromatin should be limited to heterochromatic bodies of $1 \mu$ or thereabouts adjacent to nuclear membrane.

2. In regard to the frequency of sex chromatin abnormalities in mentally defective children and the correlation between sex chromatin and sex chromosome constitution, no detailed reports have been published in Japan.

i) A study was made on 1,198 cases (male 683, female 515) of mentally defective children in Hokkaido. As a result of the sex chromatin test, 13 male and 2 female cases with sex chromatin abnormalities were found. The percentage of sex chromatin abnormalities in male cases was $1.90 \%$ which is twice as high as that in Europe and America.

ii) Studies were also made on the correlation between the sex chromatin and sex chromosome constitution of the screened cases. From the finding in sex chromatin it was shown that it was possible to surmize the sex chromosome constitution. This substantiates the significance of the sex chromatin test as a screening method. In recent years the hypothesis that the maximal number of sex chromatin is equal to the number of $\mathrm{X}$ chromosomes substracted by 1 has been set forth by some workers such as Ohno and Lyon. In regard to this the sex chromatin findings in the present work on abnormalities of the sex chromosome constitution substantiates the above theory.

\begin{abstract}
緒言
Murray L. Barr らの一連の研究により人の性の決定 が sex chromatin を検査するととにより可能となり， 近年広く臨床面に応用される所となつた。しかしながら 本検查法を一般臨床検査法として取りいれている医療 機関は決して多いこは云えない，その原因は染色方法が 簡易ではなく. 又標本の鏡検に際して sex chromatinの
\end{abstract}

* 大学院学生
判定基準がいまだ判然とされていない所にあると思われ る. 又 sex chromatin の本態についても種々と議論され て現在に至つている.

一方 sex chromatin 異常者の頻度は精薄児群で高い ことは知られて扮り, 新生児群における頻度も欧米に扔 いては報告されているが，本邦に打けるこの種の詳細な 報告をいまだ見ない。

更に sex chromatin 異常者の臨床像については数多 くの報告を見るが，殆んどが思春期後の症例についてで 
ある. 近年精薄児童を対象とした sex chromatin 検查法 の施行により思春期前の症例を得ることが可能となり， 欧米の文獻に数編の報告を見るに至つた. sex chromatin 異常の種々の型，及び各年令の症例についての臨床像の 検討は性染色体構成異常と奇形との問題に掞いて興味あ る点である。

ここに掞いて私はまず sex chromatin の本態に関す る文獻的考察 (第 1 編) を行い, sex chromatin 染色法 の検討（第 2 編）をなすとともに, sex chromatin の判 定基準（第 3 編）を定めんとした。次いで精薄児群学対 象として本検査法を施行し sex chromatin 異常者の頻 度を知るとともに screening method としての本検查法 の意義についての検討（第 4 編）を加えた．更に性染色 体構成異常症例の臨床像についての検討（第 5 編）を行 い, sex chromatin と性染色体との關係及び性染色体構 成異常と奇形との関係について研究した。

\section{第 1 編 Sex Chromatin の本態に関する交献的考 察}

sex chromatin の基礎的研究は Barr 一派により進め られた。まず1949年 ${ }^{1)}$ に成熟した雌猫の休止期の神経細 狍核に仁と密に接して存在し，仁と同様に塩基性色素に 染色される小体を発見し, nucleolar satellite と名づけ た事に始まる。そして本小体はX染色体の異質染色質に

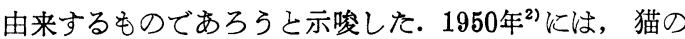
種々の部位の神経細胞において nucleolar satellite を仁 に接するもの，核質中にあるもの及び核膜に接するもの の3 型に分類し詳細な観察を行つている，即ち雌猫では 本小体は56〜87\%に見られ，その殆んどが仁に接して存 在し，その大きさは細胞の大きさにより左右されず添 $1 \mu$ を有したが，雄猫では2.1〜6.3\%にしか見られず, 多くの細胞では他の染色質と區別し難かつたと述べ， 更に本小体は Feulgen 染色にて陽性てあり, methylgreen-pyronine 染色にて緑色に染色される事より本小体 ほ desoxyribonucleic acid を含むものであろろと発表 した. 1951年 ${ }^{3)} に は$ 猫の神経翏細胞について, 又1952年 ${ }^{4)}$ には猫の19の各組織について検索を行い, 肝細胞及び 梳の腺細胞を除く全組織において, 雌では核膜に接して 50〜 67\%に，雄では 10\%以下に本小体が存在したと述 べ，本小体は仁とは直接関係のないものてあり性と関係 があるとして sex-influenced chromatin 又は単に sex chromatin の名をつけた. sex chromatin は核膜に接 し，形は一般に planoconvex をなし，良い標本では sex chromatin の中央に明るい部分があり丁度 sex ch- romatin が二分化された如く見られると述べ，とれは sex chromatin が 2 個のX染色体に由来するととによる とした. 1953年 ${ }^{5)}$ には数種の哺乳動物の神経細胞核につ いて検索して, その大多数に猫に打けると同様の所見を 得ている. 又同年 ${ }^{6)}$, 彼ら恰人の男女各50名の皮膚組織 （男女各10名の皮膚生検が含まれる）について検索を行 つて, 女では sex chromatin が平均69\% (52〜85\%) に見られたが，男で平均 $5 \%(1 \sim 14 \%)$ しか見られ ず，しかも男て見られるのは核膜に接する小さい染色質 であつたと述べている. 加えるに副腎性器症候群の女性 仮性半陰陽並びに男性仮性半陰陽の患者 2 例に皮膚生椧 を行い, 前者では sex chromatin が75\%に，後者では $4 \%$ \%か見られず，夫々その性腺の所見と一致した事 を報告している．とのことは生きている人の皮唐組織で 性の判別が可能であるととを示し, sex chromatin 検查 法が臨床的に芯用される基礎を作つたとととなる. 1954 年 ${ }^{7)}$ には人各種の器官及び組織について検索し性別の 判定がいずれす可能であつたこ報告し，1955年 ${ }^{8)}$ に恰人 の煩粘膜を木製の舌正子で擦過して得られた材料につい ても, sex chromatin が女で40〜60\%に見られたと報告 し，皮膚生検をしなくとも buccal smear にて十分に性 の判定が可能であつたと述べている.

上述の如く sex chromatin についての研究は Barr 一派によりその基礎がなされたが，その本態に関しては 女性では 2 個のX染色体の異質染色質部分が融合して sex chromatin を作り出すのであろらが，男性では性 染色体構成が XY の故に他の染色質と鑑別てきる程十 分の大きさを有した染色質を形成しえないために男性で は sex chromatin を見るととが出来ないであろろとし た.

Klinger (1957, 1958) 910) は人の embryonic membrane について検查し, sex chromatin を有した細胞の 13.5\%に bipartite form のものを認めたと報告し，そ の 1 個の染色質の大きさは $0.3 \sim 0.7 \mu$ (平均 $0.5 \mu$ ) で2 個合わせると $0.8 〜 1.4$ (平均 $1.1 \mu$ ) となり，乙 の大きさは bipartite form を呈さない sex chromatin の大きさに等しかつたと述べて，彼は Barr らの sex chromatin は 2 個のX染色体に由来するとの説を支持 した. 金井 (1958) ${ }^{60)}$ も人胎児の茂屠について検索して いるが，かかる bipartite form のものを確実に認めな かつたと述べている.

しかしながら1959年より, 種くの型の性染色体構成異 常症例が数多く報告され, sex chromatin 飞性染色体の 
比較研究が可能となり, 又一方 Ohno らによる分裂各 期の染色体の態度に関する研究が進められた結果, Barr らの説は不都合を生じ, sex chromatin 1 個のX染色 体に由来するものであると考えられる様になつた。

性染色体構成異常に関しては, Grumbach 万 (1960, 1962（ ${ }^{1112)}$ は性腺発育不全の女性で皮席及び骨䯣の 培養にて XO 性染色体構成をなし, buccal smear で sex chromatin が60\%に認められた症例を報告し, sex chromatin は 1 個のX染色体よりなるものであるると 発表した. な扮しの症例に抬いて sex chromatin が bipartite form を呈したものが見られたととより, Barr ら行 Klinger の bipartite form は 2 個のX染色体 の融合したものであるとの説は不適当であり, bipartite form は1個のX染色体が屈曲したものであろろと説 明した. De la Chapelle (1962) ${ }^{13)}$ も同様の症例を報 告している. Jacobs ら (1959) ${ }^{14)}$ が XXX 性染色体 構成の症例で sex chromatin 2 個有する細胞, 見られたと報告してょり現在まで少くも46例の XXX 症例を見るが記載ある全例に 2 個の Sex chromatin を 有する細胞が見られている(高井ら, 1964) ${ }^{15)}$. 又 Ferguson-Smith ら $(1960)^{16)}$ が XXXY 型の 2 症例に 2 個 の sex chromatin が夫タ $42 \%$ 及び $36 \%$ に認められたと 報告してょり現在まで少くも同型の11症例の報告を見る が，全例に 2 個の sex chromatin 有する細胞が見ら れている (高井ら, 1964) ${ }^{15)}$. 更に Carr ら (1961) ${ }^{17)}$ 仙 3 個の sex chromatin を有する細胞をむつた XXXX 型の女性を報告している. 又 Fraccaro 万 (1960 ${ }^{18) 199}$ は同様に sex chromatin 3 個有した XXXXY 型の 男性を報告しているが，現在まで同型の症例は21例を見 るが記載のある全例に 3 個の sex chromatin が観察さ れている (高井ら，1964) ${ }^{15)}$. 更に Kesaree ら (1963) ${ }^{20)}$ は XXXXX 型の症例を報告し, sex chromatin 4 個有する細胞が $8 \%$ に見られたと述べている.

上述の性染色体構成異常症例に於ける sex chromatin の所見を観察すると, sex chromatin は 2 個のX染色体 に由来するとの説注不都合であり，1細胞核に存在する sex chromatin の最高数は常にX染色体の数より1学 減じた数に相当するとの法則が見い出される。しかしな がら例外もあり，XO 性染色体構成の個体で sex chromatin の見られる症例 ${ }^{11 \sim 13)}$ ，及び 3 倍体の個体で XXY 性染色体構成を有し sex chromatin の見られない症例 21) 22)等はこの法則にあてはまらない。

一方，有絲核分裂過程付けるる染色体の態度に関する
研究が進られた. Ohno ら $(1959)^{23)}$ は Wistar-rat の肝細 胞について研究し, sex chromatin は 1 個のX染色体に 由来するものであろうと報告した. 即ち休止期の細胞核 を観察すると, 雌では 2 倍体の細胞核には常に 1 個の異 常凝縮体があり, 又 4 倍体の核では 2 個のそれが見られ るが, 雄では 2 倍体及び 4 倍体の核に於いても判然とし た異常凝樎体は見られなかつた。分裂前期の細胞核を钼 察すると雌の 2 倍体核では 1 個の染色体が異常凝縮する し, 又 4 倍体核では 2 個の染色体が異常凝縮するが, 雄 では異常凝縮を呈するものが見られない. 雌ては 1 個の X染色体はその全体が異質染色質よりなることより, 全 体の長さにわたつて異常凝縮する染色体はX染色体と考 えられる. 以上の所見より彼らは Wistar-rat の肝細胞 に於いては, 雄ゆX及び $\mathrm{Y}$ 染色体は異常凝縮を呈さず雌 では 2 個のX染色体のうち 1 個のX染色体の及が異常凝 縮を示し, これが休止期の細胞核で sex chromatin とし て見られるのであろうと結論した. 更と彼らは1961年 ${ }^{24)}$ 人胎児の肝細胞及び精細胞について研究した. 即ち雄の 細胞核では 1 個,の非常に小さい染色体が凝縮するが雌で はその大きさよりC群に属すると思われる 1 個の染色体 のみが強く異常凝縮する. 雄のそれは形態より G群の染 色体に似ているし, 又雌のそれは休止期核の sex chromatin の大きさにほぶー致する. 以上ょり Ohno ら (19 61) ${ }^{24)}$ は Wistar-rat の肝細胞に扔ける所見と同様に人 においても, sex chromatin は 1 個のX染色体に由来す るものであろろとの説, 所謂 sex chromatin の単一 $\mathrm{X}$ 染色体起源説を発表した。

一方 Kosin 万(1959) ${ }^{25)}$ 梳 heterogametic sex で ある家鷄（雄 ZZ, 雌 ZO）の体細胞について観察した ところ雌で sex chromatin が陽性であつたと報告して いる. このととは sex chromatin が 1 個のX染色体に 由来するとの Ohno ら (1961) ${ }^{24)}$ の説を強くした.

次いで異常凝縮するX染色体は他の全ての染色体に比 して核酸合成の時期が少く遅れていることを知る thymidne- $\mathrm{H}^{3}$ を用いた autoradiography 方法の一連の研究 によりOhno ら (1961) ${ }^{24)}$ の説は強く支持される所と なつた。即与最初 Lima-De-Faria (1959) ${ }^{26)}$ は melanoplus and scale, 及び Taylor (1960) $\left.{ }^{27}\right)$ 惊 chinese hamster について研究し, 次いで Morishima ら $(1962)^{28)}$ は 人つ末梢血白血球について研究した. Morishima ら (19 62） ${ }^{28}$ によると正常女性では核酸合成が少し遅く起る染 色体が 1 個あり, こつ染色体は大きさ及び形態上より $\mathrm{X}$ 染色体と考えられたが, 正常男性及び sex chromatin 陰 
性のXO型女性ではこの様な染色体は見られなかつたと 述べている. 彼らは, 又, 核酸合成が少し遅れて起るX染 色体は他の染色体に比して有意義の頻度で核の周辺部に 存在した事を指摘している。一方 German (1962) ${ }^{29)}$ む Morishima ろ (1962) ${ }^{28)}$ 亡同様の報告をしている. 同様の方法が性染色体構成異常症例についてもなされ， 核酸合成が遅く起るX染色体の数と sex chromatin の 数は一致する事が確認された. 即ち XXX 型では 2 個の $\mathrm{X}$ 染色体の核酸合成の時期が遅れて抢り ${ }^{30)}$, 又 $\mathrm{XXXXY}$ 型ては 3 個のX 染色体のそれが遅れていた ${ }^{3132)}$ 。とれ ら autoradiography 方法による結果は Ohno ら (19 61） ${ }^{24)}$ の sex chromatin の単一X染色体起源説に確認 を与えたとととなる. 以上ょり休止期核に执いては 1 個 の代謝的に活性で異常凝縮を起さないX染色体を除いた 他のX染色体は代謝的不活性の状態にあり, sex chromatin を形成するものと考えられる様になつた。

一方, 細胞遗伝学者の間では以前より次の事が問題と なつていた. 即ち人を含めた哺乳動物に捛いては XX型 の雌は XY 型の雄に比してX染色体上の全ての遺伝子に 関すれば 2 倍の質量を有するとととなり, 雌雄の間に遺 伝的に不均等が存在する様に思われた. このととより伴 性遺伝子については雌では雄の 2 倍見られるここを期待 したわけであるが。一般に泫人に括いても又は哺乳動物 江执いても伴性遣伝子の形質発現に著明な質的差を認め ないととより, 雌雄間の伴性遺伝子の形質発現の均等で あるととに関してはある種の機構が介在することが考え られた ${ }^{33,34)}$. この機構に関しては種々と論議されて來た が, Lyon $(1961)^{35}$ ) は Ohno ら $(1960)^{36)}$ の説を引用し, 又彼女の mouse に扮ける遗伝学的な研究より次の仮説を 提唱した. 即与女性の各体細胞核に执いては 2 個のX染 色体の 1 個は機能的に不活性であり, この不活性化は発 育の早期汇起る. 母親由来のX染色体又は父親由来の X 染色体のどちらが不活性化されるかは at random に決定 される，一度決定されるとその細胞の全ての progeny は 同じ不活性化X染色体を保持し続けるとの説で一般に lyonisation と呼ばれている. この説が正しけれ惊，1個 のX染色体が完全に異常凝縮し遗伝的に不活性化される ことにより雌雄間の伴性遺伝子の形質出現の均等さを保 つているとととなる. 又哺乳類の雌ではX染色体上の遺 伝因子に関する現象型に限り, 自然的なmosaicを示すこ ととなる. 人の伴性遗伝子についての報告は McKusick (1962) ${ }^{37)}$ 及で Lyon (1962) ${ }^{38)}$ がしている.

この lyonisation を裏付ける事実は正常野生色因子を
有するX染色体と mutant 毛色因子を有するX染色体よ りなる mouse の毛色注野生色と mutant 毛色を呈する こと ${ }^{35)}$, 又野生黒色因子をもつX染色体々黄色毛色因子 をもつX染色体を有する雌猫は三毛猫であること ${ }^{35)}$, 更 に人に捛いてはグルコースー6一燐酸脱水素醭素不全症 39) 41), Duchenne 型筋菱縮症 ${ }^{42) 43)}$ 等の女性で認められ ている、しかしながら lyonisation を満足しないもの に Xga と呼ばれる blood-group antigen の伴性遺伝 子があり ${ }^{44 \sim 46)}$, 又 2 個のX染色体の短腕が切断欠損 し，それぞれの長腕がその着絲点で接合して出来たと考 えられる iso-X 染色体と正常のX染色体よりなる個体 47 511ではその sex chromatin を形成するのは全て iso$\mathrm{X}$ 染色体であることである25253. 後者に関しては $\mathrm{Ga}$ rtler ら $(1963)^{\left.{ }^{54}\right)}$ は iso-X, X 型及び XO 型の個体 に掞いても lyonisation は起るのだが，それぞれX染 色体の不活性化した細胞は生存不能と考えられる故, こ れら個体は lyonisation には反しないと述べている. 又 Stewart ${ }^{55 \sim 57)}$ は伴性遗伝子の座位は iso-X, X 症例など の観察より短腕に含まれるものでありX染色体の長腕は sex chromatin 形成にあたるものであろうと述べてい る. 更に色盲及び $\mathrm{Xg}^{\mathrm{a}}$ などによつてX染色体が母親由 来のものか, 又は父親由来のものかを判明しょうとする 報告がなされている. 以上の如く近年 Lyon の仮説と相 まつて, sex chromatin がX染色体の全体より形成され るものか又はその一部より形成されるものかの問題, 過 剩のX染色体は母親由来のものか或いは父親由来のもの かの問題, 更には性染色体構成異常者の臨床についての 遺伝的機構などの点に関して, X染色体上の遺伝子学的 研究より究明しょうとする努力がなされている.

\section{第 2 編 Sex Chromatin 染色法の検討}

sex chromatin 染色法は現在まで種々と報告されてい るが，一般臨床検查法として用いるに理想的な条件は染 色操作の簡単なとと,及び検鏡に際して sex chromatin が判然と観察し得る標本が得られることである.

私は sex chromatin について研究を進めるにあたり, まずての点を究明すべく, 従来より広く用いられている Feulgen 法, sex chromatin の鑑別染色法と云われる Guard 法, 迅速簡易染色法として報告されている aceto-orcein 法, 更にどこの検査室に於いても行われてい る hematoxylin and eosin 法及び Giemsa 法の5 法を 正常者及び性染色体構成異常者に施行して比較検討を試 みた。

\section{1. 研究材料及び方法}


検查材料を採取する際には被検者の苦痛を可及的最小 限にし，しかも検查するに十分の材料が得られれば良い。 口胿粘膜細胞はこの点で最も適したものであり, 私恃本 研究に扔いて，もつぱら buccal smear を検查材料とし た. まず金属性舌圧子で被検者の煩粘膜を少しく強く擦 過し得られた smear を slide glass 上に塗抹し, 他の slide glass をとれに合し手圧を加えることにより同時 に2 枚の標本を得た. この操作により可及的一様溷剥離 細胞を slide 面に塗抹することが出來, 加えるに染色操 作過程に抢ける細胞の slide 面よりの離脱を少なからし めることが出來た． 固定は $95 \%$ エチルアルコールを用 いた．たら゙し Feulgen 法にては卵白グリセリンを用い て smear を塗抹した. 又 aceto-orcein 法にては他の 4 法とは全く異なり上記の塗抹固定の操作を必要としな い. 染色法は下記の 5 方法を用いた。

i Guard 法 (Guard, 1959 : 中川, 1961 ${ }^{58599}$ ) : 私 は Biebrich scarlet $は$ 和光純菒工業会社製, fast green FCF は東京化成工業会社製, phosphotungstic acid 百 で phosphomolybdic acid はキシタ化学会社製のもの をそれぞれ用い，Guard 法の変法（中川，1961） ${ }^{59)}$ 用いた。

ii. Feulgén 法 (金井, 1958) ${ }^{60}$

iii. aceto-orcein 法 (Sanderson \& Stewart 1961) ${ }^{61)}$ : orcein は Merk 社製のものを用いた。本法を sex chromatin 染色法として用いた文塬を本邦に見ないので こに紹介しょう. orcein $1 \mathrm{~g}$ 亿氷酢酸 $45 \mathrm{cc}$ 加え煮沸・ 冷却次いで濾過したものを stock solution とし，この stock solution $45 \%$, 蒸溜水 $55 \%$ の混合液を滤過して得 られたものが simple aceto-orcein 染色液であり, 又 stock solution及び70\%乳酸を等量に混じ濾過したものが lacto-aceto-orcein 染色液である. 被検者の煩粘膜より 得られた smear の 1 滴を slide glass の中央にのせ，その 上に上記染色液の 1 滴を加えて cover glass で覆い, こ のslide glass 滤紙の間にはさんで手圧する．この操作 により細胞は一層に拡がり, 又余剩の染色液を除くこと
が出來る.すぐ鏡検可能であるが本法は永久標本にあら ずして lacto-aceto-orcein 法では室温にて 6 週間, simple aceto-orcein 法では冷蔵庫保存にて数週間の保存に たえる.

iv. Giemsa 法：15 30分間 Giemsa 液に作用させ た.

v. hematoxylin and eosin 法: hematoxylin 液に 3 ～5 分間, 及び eosin 液に 1 分間夫々作用させた。

鏡検に際しては弱桩大にて比較的染色良好の部位を撰 択し，200〜 500個の細胞核を算定した. 核濃縮等退行 変性を認めた細胞は算定外とした. 又 sex chromatin は 核膜に接して大きさ $1 \mu$ 内外の塩基性色索に濃染する小 体のみとした.

\section{2. 研究結果}

i. 正常者

Guard 法は男女各 100名について, 他の 4 法注男女 各10名について検索した. 各染色法による sex chromatin の出現頻度は第 1 表に示される.

鏡検に際し最も sex chromatin が判然とするものは Guard 法であつた. これは sex chromatinが赤色に, 細 胞質及び他の核内要素が緑色に対比染色されるからであ る. 次いで Feulgen 法及び aceto-orcein 法が比較的 良く sex chromatin を観察出来たが, aceto-orcein 法 では細胞が一層になつているため算定容易であり，ての 点で Feulgen 法より優れていた. Giemsa 法及び hematoxylin and eosin 法は良好に染色された部位では sex chromatin 比較的良く観察し得るが, 多くの場合 色素顆粒のため判定困難となり, 又他の異常凝縮体との 鑑別が困難の事が多く, 上記 3 法に比して著しく劣つて いた. sex chromatin の判定の難易はその出現頻度に関 係し, 第 1 表に示される如く女性について見ると Guard 法が25.5 80.5\% (平均 $46.88 \%$ ) と最も高い出現頻度 を示し, 次いで Feulgen 法, aceto-orcein 法, Giemsa 法及び hematoxylin and eosin 法の順であつた。

染色操作の難易の点に関しては, smear 1 滴に染色液

第 1 表 正常男女の染色法別によるSex Chromatin の出現頻度（\%）

\begin{tabular}{|c|c|c|c|c|}
\hline 色 & 数 & 男（平 均） & 例 & （平 均） \\
\hline Guard 法 & 100 & $0 \sim 2.0(0.365)$ & 100 & $25.5 \sim 80.5(46.88)$ \\
\hline Feulgen 法 & 10 & $0 \sim 1.0(0.35)$ & 10 & $23.5 \sim 41.0(31.4)$ \\
\hline Aceto-orcein 法 & 10 & $0 \sim 2.0(0.5)$ & 10 & $12.5 \sim 35.0(22.75)$ \\
\hline Giemsa 法 & 10 & $0 \sim 2.0(0.8)$ & 10 & $7.0 \sim 32.5(13.0)$ \\
\hline $\mathrm{H}-\mathrm{E}$ 法 & 10 & $0 \sim 1.5(0.7)$ & 10 & $4.0 \sim 15.0(9.15)$ \\
\hline
\end{tabular}


第 2 表 性染色体構成異常者の染色法別による Sex Chromatin の出現頻度（\%）

\begin{tabular}{|c|c|c|c|c|c|c|}
\hline 性染色体構成 & $\begin{array}{l}\text { Sex Chrom- } \\
\text { atin の数 }\end{array}$ & Guard 法 & Feulgen 法 & $\begin{array}{c}\text { Aceto- } \\
\text { orcein 法 }\end{array}$ & Giemsa 法 & H-E 法 \\
\hline $\mathrm{XXY}$ & 1 & 67.0 & 14.0 & 25.0 & 12.0 & 4.5 \\
\hline $\mathrm{XXXY}$ & 2 & 42.6 & 12.8 & 14.5 & 2.0 & 10.0 \\
\hline $\mathrm{XXX}$ & 2 & 20.8 & 11.0 & 11.5 & 2.5 & 6.0 \\
\hline $\mathrm{XXXXY}$ & 3 & 37.6 & 15.4 & 11.5 & 2.4 & 12.4 \\
\hline
\end{tabular}

1 滴学加えるだけですむ aceto-orcein 法ぶ最も簡易で， 次いで Giemsa 法㣻び hematoxylin and eosin 法であ つた. Guard 法は fast green FCF 液に作用させる時間 が一定して扮らず各標本につき時々その染色過程を鏡検 しなければならぬ点等である程度の経験が要求される. 最も染色操作の煩雑なむの梳 Feulgen 法であつた.

ii。性染色体構成異常者

第 4 編の研究に上り発見した XXX，XXXY 贳び $\mathrm{XXXXY}$ 型の各 1 例並びに XXY 型の 1 例について比 較染色した (第 2 表).

sex chromatin 2 個又は 3 個有する症例では, Guard 法による標本が最も判然と観察可能であつた. Feulgen 法及び aceto-orcein 法にては 2 個又は 3 個の sex chromatin 明瞭に観察出来る核は Guard 法による標 本に比較して非常に少なかつた. Giemsa 法及び hematoxylin and eosin 法では非常に判然としなかつた.

\section{3. 考按}

sex chromatin の染色法は種々と報告されて来たが， いずれも sex chromatin が desoxyribonucleic acid に 富み, 塩基性色素に濃染される性質を有することに基づ いている.

Barr ら $(1950,1952)^{2) 4}$ 仗 cresyl echt violet 法, hematoxylin and eosin 法, Feulgen 法, methyl green pyronine 法及び thionine 法を用い，Lennox (1956） ${ }^{62)}$ は gallocyanine 法, Eskelund (1956) ${ }^{63}$ 性 fuchsin 法, Greenblatt 弓 (1957） ${ }^{64)}$ は pinacyanol 法を用い， Klinger 弓 (1957) ${ }^{65}$ 放弱酸加水分解後飞 thionine 作用させる方法を報告している，本邦に执いても cresyl echt violet 法 $^{66 \sim 68)}$, Feulgen法 ${ }^{60) 69) 70)}$ 及び hematoxylin and eosin 法 $^{71772)}$ ，が賞用されて来たが，他に Giemsa 法, Papanicolaou 法, Unna-Pappenheim 法等 ${ }^{66 \sim 68) 73)}$ も陚みられた。これら染色方法はいずれも sex chromatin が他の核内体より濃染されることにより判定される
わけであり,鏡検に際してある程度の経験を必要とした。

Guard (1959) ${ }^{58)}$ 㳉 Biebrich scarlet 及び fast green FCF を核染色剤として用い sex chromatin のみを赤色 に他の核内体を緑色に対比染色する所謂 sex chromatin 鑑別染色法を発表した。即ち彼は vaginal smear 材料 として hematoxylin and eosin 法, cresyl echt violet 法, Klinger's thionine 法及で BS-FG 法を比較検討して, BS-FG 法が最も sex chromatin を判然と観察出来, か つその出現頻度が最も高いと報告し buccal smear では 女で41 69\%（平均55\%）に見られたと報告している. 中川 (1961） ${ }^{59)}$ 汶本法の追試を行い女の buccal smear で sex chromatin が29.0 36.7\% (平均 $32 \%$ ) に, 又 松永 (1961) ${ }^{74)}$ は $42 \sim 81 \%$ (平均 $71.3 \%$ ) に見られたと 述べ，本法は sex chromatin を核内の他の疑しい染色 質塊より鑑別するととが容易である点て優れていたと報 告している. 自験にても Guard 法は他の 4 法に比して sex chromatin の検索が最も容易で，その出現頻度も女 で25.5 80.5\% (平均 $46.88 \%$ ) と最も高かつた。第 2 表の性染色体構成異常症例についての結果を見ても同様 のことが強調される．中川 (1961） ${ }^{59}$ は Guard 原法の 主染色用の濃度を半量にした 改良法を用いることによ り，染色時間を短縮させ，同時に 4 枚の標本を染色し 45 分，60分，75分及び90分と fast green FCF 作用させ る事により必ず 1 枚は至適な染色標本が得られる故，そ の染色過程を知るために鏡検する必要がないと述べてい る. 自験にては最適の染色標本を得るための fast green FCF 作用時間は 30 分乃至 180分の幅が見られ，種々の 条件即与室温 . 固定時間, 染色液の新鮮度等が染色時間 に関係するこ考えられ，私は染色過程を見るため時及鏡 検することにした。 この操作が比較的難て，ある程度の 経験が必要であると思われた。

sex chromatin の迅速簡便な染色法としては, Thiriez $(1956)^{\left.{ }^{25}\right)}$ が染色体研究で広く使用されている orcein 
法老度用し, Sanderson \& Stewart $(1961)^{61)}$ 本染 色剂を推奖している. 本邦に於いても鈴木ら (1956) ${ }^{76)}$ が cresylecht violet, gentiana violet 艾げ fuchsin の

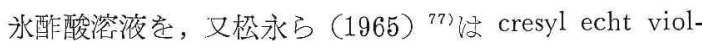
et, Hoffmann's violet 敒び Biebrich scarlet の水䤏酸

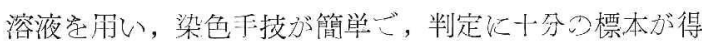
られる己報告している。私怡 Sanderson \& Stewart (19 61） ${ }^{61)}$ の報告による aceto-orcein 法定武反なが，火で sex chromatin の出現頙度が12.5 35.0\% (平均 22.75 \%) \&. Guard 法比比して明膫な sex chromatin 学筧

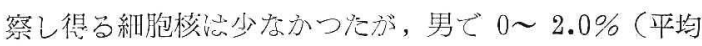
0.5\%)であるので, 半定上の困蜼空感じなかつた, 本 法の染色操作は全く簡监で経験は殆しざ必要とせず，染

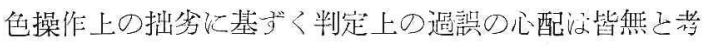
えられ，更に染色試薬も安伍で染色液調整も簡単である 点で一般臨床検查としては最適の染色方法と思われた。

\section{4. 結 語}

1）正常者政び性染色体構成異常者について buccal smear 学材料として Guard 法, Feulgen 法, acetoorcein法. Giemsa 法忍び hematoxylin and eosin 法 を施して，染色操作艾び sex chromatin の㰸索上の難

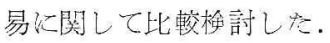

2) Guard 法引゙最も sex chromatin 判然己钼察す ることが可能であり，最も高い出現頻度示したが，そ の染色操作にある程宽の経歌の必要性老䍂めた。

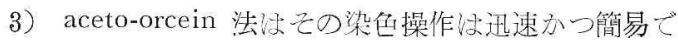

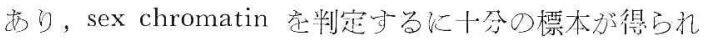
る点で一般陵床検查法としては最適と思われた。

\section{第 3 編 Sex Chromatin の判定基準に関する検討}

染色標本を鏡検し sex chromatin の所胃学判定する 際㵊も問題となるのはその出現頻度てある. sex chromatin の出現頻度心検查材料己して用いる組織の種類及
び標本が組織標本である穴剝離細胞㳂抹標本であるかで 異なるととが容易に考えられ，又第２編で既述の如く標 本の固定，染色污法の相違灭びその技術的な良否により 左右され得るが, その他倹者が核内のぞの位置に存在 寸るもの sex chromatin 上するか即占 sex chromatin の判定基準の相違が関䋆年る。核膜に接する異質染色 質のみ老 sex chromatin とするもの, 又榜膜より遊離 して存在するもの安含妙て算定するすの等, 報告者に より異なり， sex chromatin の判定基準红関して詳細な

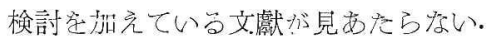

そこで私标核内の異質染色質む容易に篗察可能な $\mathrm{Gu}$ ard 法色用いて，正常例死び性染色体棈成異常例につい て核内の異質染色啠空算定して sex chromatin の判定 基準学求好んとした。

\section{1. 研究材料及び方法}

正常男女各 100 名及び性染色体構成其常18例（第 4 編

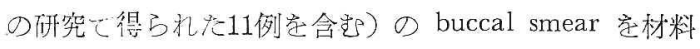
とした、染色法は前編の結果より Guard 法が最も適し ているのでこれを用いた．正常例では各標本につき 200 個の細胞核を算定し，又異常例では 200〜 500個の細胞

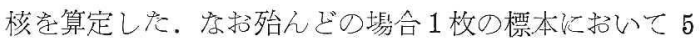
00個以上の細胞を算定し得たが，稀飞採取制離細胞无少 いため, 又は染色過程に招ける離脱細胞栄多いために算 定するに十令の細饱汃観察されない事があつたが，との 場合は再採取歨行い梌查した。

算定際しては Biebrich scarlet の赤色有し大きさ

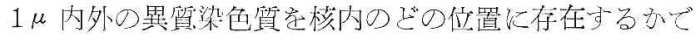
次の如く分類した（第 1 図）。

i。㤥膜比接古るもの (marginal).

ii。榜膜に接するものと核膜の近くに存在するもの (marginal+submarginal).

ii，核膜に接するものと核の中心部に存在するもの (marginal+center).

第 1 図 異質染色質の分類 (Guard 氏染色法， $\times 1,000)$

\begin{tabular}{|c|c|c|c|c|c|c|c|c|c|}
\hline 分類記号 & i & ii & iiii & iv & V & vi & vili & viiil & $i x$ \\
\hline 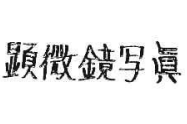 & & & ets & & & & & & 6 \\
\hline Schema & & & & & & & & & \\
\hline
\end{tabular}


第 3 表 正常男女の異質染色質の出現頻度（\%)

\begin{tabular}{|c|c|c|}
\hline & (平 均) & 女 （平 均） \\
\hline i. Marginal & $0 \sim 2.0(0.3)$ & $15.0 \sim 70.0(35.1)$ \\
\hline ii. Marginal+Submarginal & & $0 \sim 4.0(0.9)$ \\
\hline iii. Marginal+Center & $0 \sim 1.0(0.0)$ & $3.0 \sim 30 \quad(10.2)$ \\
\hline iv. 2 marginal & & $0 \sim 3.0(0.6)$ \\
\hline $\mathrm{i} \sim$ iv. & $0 \sim 2.0(0.4)$ & $25.5 \sim 80.5(46.9)$ \\
\hline v. Submarginal & $0 \sim 7.5(1.0)$ & $0 \sim 7.5(\not 2.2)$ \\
\hline vi. Center & $2.5 \sim 26.5(10.9)$ & $4.0 \sim 21.5(10.3)$ \\
\hline vii 2 center & $0.5 \sim 20.0(4.0)$ & $0.5 \sim 26.5(5.3)$ \\
\hline $\mathrm{v} \sim$ vii. & $3.0 \sim 45.5(15.9)$ & $6.0 \sim 38.5(17.7)$ \\
\hline viii. Small marginal & $0 \sim 5.0(0.8)$ & $0 \sim 4.0(1.0)$ \\
\hline ix 2 small marginal & $0 \sim 1.0(0.0)$ & $0 \sim 3.5(0.9)$ \\
\hline $\mathrm{i} \sim \mathrm{ix}$. & $3.0 \sim 51$ & $43.0 \sim 95.5(65.5)$ \\
\hline
\end{tabular}

第 2 政常男女の異質染色質の出現頻度

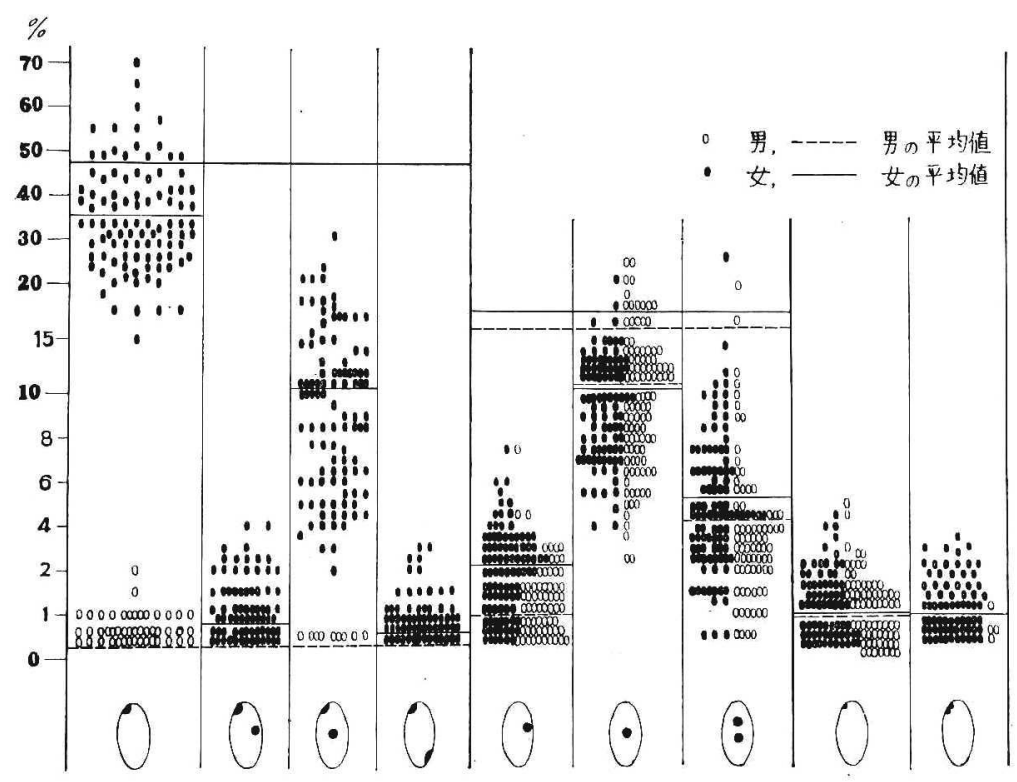

iv 核膜に接して 2 個見られるもの ( 2 marginal).

v. 核膜の近く《存在するもの (submarginal).

vi. 核の中心部にあるもの (center). vii，核の中心部に 2 個めるもの ( 2 center).

viii．核膜に接して大きさ1/2のもの(small marginal).

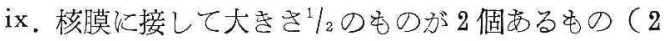
small marginal).

な扮核膜の近くに存在するものとは核の $1 / 2$ 半径の同心

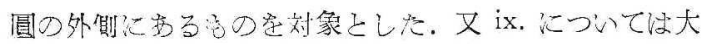

きさ1/2のものが 2 個非常に近接してみられるものを対象 こした，異常例に执いては上記分類の他に，異質染色質 が 3 個及び4 個見られる場合があり，これらも分類算定 LT.

\section{2. 研究結果}

正常例について缽 3 表及び第 2 図に示す如くであ る. i.〜iv.の核膜に接する群では女性25.5〜 80.5\%(平 均 $46.9 \%$ ) D出現頻焚であるが，男は 0〜 2.0\%（平均

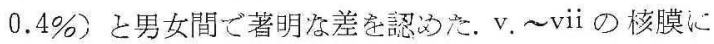


第 4 表 性染色体構成異常症例飞於ける異質染 色質（核膜に接するもののみ）の出現 頻度 $(\%)$

\begin{tabular}{|c|c|c|c|c|c|c|}
\hline \multirow{2}{*}{ 症 } & \multirow{2}{*}{ 例 } & \multirow{2}{*}{$\begin{array}{l}\text { 性 染 色 } \\
\text { 体 構 成 }\end{array}$} & \multicolumn{4}{|c|}{$\begin{array}{l}\text { 核膜に接する異質染色 } \\
\text { 貿の数 }\end{array}$} \\
\hline & & & 1 & 2 & 3 & 4 \\
\hline $\mathrm{K}$ & A & XXY & 65.0 & 2.5 & & \\
\hline$M$ & $\mathrm{Y}$ & " & 62.0 & 0 & & \\
\hline $\mathbf{M}$ & $M$ & "I & 66.0 & 1.5 & & \\
\hline $\mathrm{T}$ & $\mathrm{N}$ & "I & 57.5 & 4.5 & & \\
\hline$G$ & $\mathrm{~T}$ & "I & 44.0 & 1.0 & & \\
\hline$M$ & $\mathrm{U}$ & " & 61.0 & 1.0 & & \\
\hline $\mathrm{N}$ & $\mathrm{K}$ & " & 55.0 & 0 & & \\
\hline $\mathrm{T}$ & $\mathrm{Y}$ & " & 72.5 & 2.0 & & \\
\hline$Y$ & A & "I & 45.0 & 0 & & \\
\hline $\mathrm{Z}$ & $\mathrm{S}$ & "I & 67.0 & 0.5 & & \\
\hline $\mathbf{M}$ & $\mathrm{N}$ & " & 64.5 & 0 & & \\
\hline $\mathrm{K}$ & $\mathrm{T}$ & " & 47.5 & 0 & & \\
\hline $\mathrm{N}$ & $\mathrm{N}$ & " & 52.5 & 0 & & \\
\hline $\mathrm{N}$ & $\mathrm{S}$ & "I & 58.0 & 0.5 & & \\
\hline $\mathrm{O}$ & $\mathrm{T}$ & XXYY & 65.0 & 0.5 & & \\
\hline $\mathrm{K}$ & $\mathrm{T}$ & XXXY & 34.6 & 42.6 & 1.6 & \\
\hline $\mathrm{S}$ & $\mathrm{T}$ & $\mathrm{XXX}$ & 30.2 & 20.8 & 0.6 & \\
\hline $\mathrm{Y}$ & $\mathrm{K}$ & XXXXY & 20.0 & 33.6 & 37.4 & 1.0 \\
\hline
\end{tabular}

接しない群では女で 6.0 38.5\% (平均17.7\%), 男で $3.0 \sim 45.5 \%$ (平均 $15.91 \%$ ) と男女間の差活殆んどな かつた。 viii. 及び xi. の大きさ $1_{2}$ の群では女で $1.9 \%$, $0.8 \%$ の平均値を示した. 又異質染色質を 2 個有する もの, 即ち ii.〜iv. 及び vii.の群は女で 5.5 60.5\% (平均 $16.0 \%$ ), 男で $0.5 \sim 20.5 \%$ (平均 $4.1 \%$ ) であつ た.

異常例について核膜に接するものの及を算定した結果 注第 4 表に示す如くであり, 又核内の全ての位置に存在 する異質染色質で大きさ $1 \mu$ 内外のものを算定した結果 は第 5 表に示される.XXY 14例及び XXYY 1 例につ いて核膜に接するもののみを算定すると 1 個のものが 44.0〜 72.5\%であり, 又 2 個見られるものが $0 \sim 4.5 \%$ であつた. XXXY症例では核膜に接して 2 個あるものは $42.6 \%$ 3 個見られたものは $1.6 \%$ みであつた. XXX 症例では 2 個のものが $20.8 \%$ K，3 個見られたものは $0.6 \%$ にすぎなかつた 更に XXXXY 症例では 3 個の ものが $37.4 \% ， 4$ 個のものが 1.0\%であつた. しかしな がら核内の全ての位置に存在する異質染色質を算定する こ，XXY 及び XXYY 症例では 2 個のものが 4.5 $43.0 \%$ KXXY及び XXX 症例では 3 個のものが夫ぬ
第 5 表 性染色体構成異常症例飞於ける異質染 色質（核内の全ての位置に存在するも の）の出現頻度（\%)

\begin{tabular}{|c|c|c|c|c|c|c|}
\hline \multirow{2}{*}{ 症 } & \multirow{2}{*}{ 例 } & \multirow{2}{*}{$\begin{array}{ll}\text { 性 染 色 } \\
\text { 体 構 成 }\end{array}$} & \multicolumn{4}{|c|}{$\begin{array}{l}\text { 核内の全ての位置に存 } \\
\text { 啠る質染色の数 }\end{array}$} \\
\hline & & & 1 & 2 & 3 & 4 \\
\hline $\mathrm{K}$ & A & $\mathrm{XXY}$ & 55.0 & 27.5 & & \\
\hline $\mathrm{M}$ & $\mathrm{Y}$ & " & 77.0 & 7.0 & & \\
\hline M & 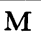 & " & 75.0 & 12.0 & & \\
\hline $\mathrm{T}$ & $\mathrm{N}$ & " & 60.0 & 9.0 & & \\
\hline G & $\mathrm{T}$ & " & 49.5 & 16.5 & & \\
\hline M & $\mathrm{U}$ & " & 71.5 & 11.0 & & \\
\hline $\mathrm{N}$ & $\mathrm{K}$ & " & 70.0 & 5.0 & & \\
\hline $\mathrm{T}$ & $Y$ & "I & 65.5 & 25.0 & & \\
\hline $\mathrm{Y}$ & A & " & 42.0 & 43.0 & & \\
\hline $\mathrm{Z}$ & $\mathrm{S}$ & " & 58.0 & 27.5 & & \\
\hline M & $\mathrm{N}$ & " & 71.0 & 8.5 & & \\
\hline $\mathrm{K}$ & $\mathrm{T}$ & " & 51.5 & 23.5 & & \\
\hline $\mathrm{N}$ & $\mathrm{N}$ & " & 63.0 & 24.5 & & \\
\hline $\mathrm{N}$ & $\mathrm{S}$ & "' & 69.5 & 8.5 & & \\
\hline $\mathrm{O}$ & $T$ & $X X Y Y$ & 81.0 & 4.5 & & \\
\hline $\mathrm{K}$ & $\mathrm{T}$ & $\mathrm{XXXY}$ & 14.5 & 51.0 & 24.0 & \\
\hline $\mathrm{S}$ & $\mathrm{T}$ & $\mathrm{XXX}$ & 22.5 & 46.0 & 13.5 & \\
\hline $\mathrm{Y}$ & $\mathrm{K}$ & XXXXY & 2.5 & 13.0 & 60.0 & 22.5 \\
\hline
\end{tabular}

$24.0 \%$ 及び $13.5 \%$, 更に XXXXY 症例では 4 個のも のが22.5\%に見られた。

\section{3. 考 按}

Barr ら $(1950 ， 1953)^{225)}$ は猫及び他の哺乳動物の神 経細胞を検索して， sex chromatin を核小体に接するを の, 核質内に遊離するもの及び核膜に接するものの 3 型 に分類している. Moore ら (1953） ${ }^{6}$ 注人の皮唐生検 について検査し最も多い型は核膜に接して存在する 1 個 の planoconvex 型のものであるが, たまたま核質中に 遊離し又は核小体に接する sex chromatin があると述 べている. 又 Marberger ら (1955) ${ }^{78)}$ は核膜に接する もの及び核膜の近くに存在するものを sex chromatin と して算定している.

Guard (1959) ${ }^{58)}$ は BS-FG 法に於いては sex chromatin が特異的に Biebrich scarlet の色を保持して赤色 をとどめるため核内のどこにあつても sex chromatin と して判定可能であると述べている. しかしながら Barr

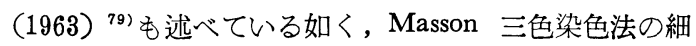
胞質染色として使用される Biebrich scarlet の sex chromatin に対する特殊親和性及び BS-FG 法に使用され る他の色素との間の化学的反応は解明されているとは云 
えず, Guard の述べる如く大きさ $1 \mu$ 内外で赤色を保持 する染色質塊が全て sex chromatin であるとの報告に は疑問がもたれる。

本邦に於いては安達 $(1957)^{68)}$ 及び佐藤ら (1957) ${ }^{67)}$ は核膜に接しているもののみを sex chromatin として 算定している。金井 (1958） ${ }^{60}$ 核膜から遊離している sex chromatin も認めるが判定し難い場合には算定より 除外したと記している. Guard 法の追試を行つた中川 (1961） ${ }^{599}$ 恔膜より遊離して核質中にあるものをも sex chromatin として算定しているが, 辺縁と内部に 1 個ず つあるもの, 又は内部に 2 個あるものについては正常の 女で sex chromatin が 2 個ある事は考えられないとし ててれらを算定より除外している.

私は正常男女の核内の全ての異常染色質について算定 観察した結果, 次の 3 点より一般臨床検查法として sex chromatin を判定する場合には大きさ $1 \mu$ 内外の核膜 に接して存在する異質染色質の及を算定すべさであると の見解を得た。

i. 核膜に接して存在する異質染色質の出現頻度は女 で25.5〜 80.5\%(平均 $46.9 \%$ )であるが,男では 0 2.0\% （平均 $0.4 \%)$ で男女の差が著明であり男では核膜に接す るものは殆んど見られないと云つても過言ではない.

ii. 核膜より遊離している異質染色質の出現頻度は女 で $6.0 \sim 38.5 \%$ (平均 $17.7 \%$ ), 男で $3.0 \sim 45.5 \%$ (平均 15.9\%)で男女共漂ざ同じ頻度に見られる。

iii。もしも核膜より遊離して存在する異質染色質をも sex chromatin とするならば, 正常の女性で 2 個の sex chromatin を有する細胞が 5.5 60.5\% (平均 16.0\%) に見られることになり，第 1 編で既述した sex chromatin の数柱X染色体の数より常に 1 個すくないとの説に 反することになる。

しかしながら核膜に接していない異質染色質は全て sex chromatin でない即ちX染色体に由来するものでな いとは云えず, 又同様に核膜に接して存在する異質染色 質が全てX染色体に由来するものであるとの確証はなに もない. 男性で核膜に接して見られた女性と同様の異質 染色質が $0 \sim 2.0 \%$ (平均 0.4\%) 観察し得たが，乙 れは核膜より遊離して存在する常染色体由来の異質染色 質がたまたま核膜に接したものであろうと推測したい。 又女性で核膜に接する 2 個の異質染色質を 0 〜 $3.0 \%$ （平均 $0.6 \%$ ）に見られたが，乙れも同様汇考元たい. Klinger $(1957)^{9)}$ も女性で 2 個のものが 0.2 2.2\% （平均 $0.7 \%$ ）に見られたこ報告している.
なお男性に見られる核膜に接して大きさ $1 / 2$ の異質染色 質は始め 1 個のX染色体であろろと思われたが ${ }^{299}$, Ohno \& Makino (1961) ${ }^{24)}$ はY染色体の異常凝縮したも のであろうとした. Guard (1959) ${ }^{58}$ はかかる小体を男 に10 20\%の頻度に見たと述べているが自験では男で 0 $\sim 5.0 \%$ (平均 $0.8 \%$ ), 女で 0 $4.0 \%$ (平均 $1.0 \%$ ) で持に男女の差は見られず，性染色体とは関係のない染 色質塊に思えた. 又 $1 / 2$ の大きさの異質染色質塊ぶ 2 個接 近して見られるものについては，始め Graham ら (19 52) ${ }^{4}$ 及び Klinger (1957) ${ }^{9}$ は bipartite form $の$ sex chromatin と呼び, sex chromatin が 2 個のX染色体よ りなるととに基づくと報告したが，Grumbach ら（19 60（ ${ }^{12)}$ は 1 個のX染色体の屈曲したものであろうと述べ ている. 自験ではこの様な小体は女で 0〜 3.5\% (平均 0.9\%)，男で 0 1.0\% (平均 $0.025 \%$ ) に認められた

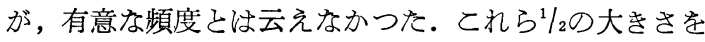
有する小体についてはその出現頻度より sex chromatin の所見を判定する際に算定より除外してょいと考える.

次に性染色体構成異常症例の自駼結果より見ても，核 膜にのみ接する異質染色質を算定した場合には，sex chromatin の数はX染色体の数より常に 1 を減じた数に等 しいとの法則に合致するが，核内の全ての位置に存在す る異質染色質をも算定すると第 5 表の如くこの法則を満 足しない，正常男女について観察して核膜に接して存在 するもののみを sex chromatin とすべきであるとの私 の見解は, 異常例の観察結果よりなお一層強調されるこ ととなる.

\section{4. 結 語}

1).正常男女各 100 名及び性染色体構成異常 18 例の buccal smear について Guard 法を施行し，異質染色質 の核内位置別出現頻度を検討した。

2).正常別については，核膜に接する異質染色質の出 現頻度は女で $25.5 \sim 80.5 \%$ (平均 $46.9 \%$ ), 男で 0 2.0 $\%$ (平均 $0.4 \%$ ) で男女の 差が著明であつたが, 核膜に 接していない異質染色質は女で 6.0 38.5\%（平均 17.7 \%), 男で 3.0 45.5\% (平均15.9\%) と性別による差は 殆んごなかつた. 又 2 個の異質染色質が女で 5.5 60.5 $\%$ (平均 $16.0 \%$ ) に見られたが，核膜より遊離する異質 染色質をも sex chromatin とするならば，性染色体構成 XXの正常女性で 2 個の sex chromatin が有意の頻度 に見られることとなり, sex chromatin の数恃X染色体 の数より 1 を減じた数に等しいとの法則に反するととと なる. 以上の点より sex chromatin は核膜淁する大 
きさ $1 \mu$ 内外の異質染色質のみとすべきであるとの見解 を得た。

3).性染色体構成異常例についての観察結果は, 正常 例で得られた私の見解をなお一層強めるものであつた。

\section{第 4 編 精薄児群における Sex Chromatin 異常者} の頻度及び Screening Method としての Sex Chromatin 検查法の意義についての検討

近年, 性異常症例については勿論のこと, 精薄児, 精 神分裂症患者及び新生児等に sex chromatin 検查が廐 用されて来た。中でも sex chromatin 異常者の多くが 精薄を伴うことより精薄児群を対象とした報告が欧米に 於いて多く見られるが，本邦に於いてはいまだての種の 詳細な報告を見ない。

私は主に北海道の精薄児童について sex chromatin 検查法を施行して, sex chromatin 異常者の頻度を知る と共に, 本検查法の screening test としての意義につい て検討を加えた。加えるに本研究により，種々の $\operatorname{sex}$ chromatin 異常者を得て sex chromatin 已性染色体構 成の関係を追求出来ることを期待し, 更には思春期前の sex chromatin 異常者を得てその臨床像を研究出来るこ とを期待した。

\section{1. 研究材料及び方法}

北海道の精薄施設 9 及び特殊学級を併置する学校 $31 の$
第 6 表 精薄児群に於ける Sex Chromatin 異常者の頻度（\%）

\begin{tabular}{|c|c|c|c|c|c|c|c|}
\hline & \multirow{2}{*}{$\begin{array}{l}\text { 検查施 } \\
\text { 行例数 }\end{array}$} & \multirow{2}{*}{$\begin{array}{l}\text { 異常 } \\
\text { 者数 }\end{array}$} & \multicolumn{3}{|c|}{$\begin{array}{l}\text { Sex Chro- } \\
\text { matin の数 }\end{array}$} & \multirow{2}{*}{ 頻 度 } \\
\hline & & & & 1 & 2 & 3 & \\
\hline \multirow{3}{*}{ 男 } & 精薄施設 & 343 & 4 & 2 & 1 & 1 & 1. 17 \\
\hline & 特殊学級 & 340 & 9 & 9 & & & 2.65 \\
\hline & 計 & 683 & 13 & 11 & 1 & 1 & 1.90 \\
\hline \multirow{3}{*}{ 女 } & 精薄施設 & 235 & 1 & & 1 & & 0.43 \\
\hline & 特殊学級 & 280 & 1 & & 1 & & 0.36 \\
\hline & 計 & 515 & 2 & & 2 & & 0.39 \\
\hline
\end{tabular}

精薄児童, 男 683 名及び女 515 名計 1,198 名について検 查した. 精薄施設の児童の多くは I.Q. が60以下を示し, 特殊学級の児童のそれは60〜80が殆んどであつた。

検查材料は全て buccal smear を用い, Guard 法の 変法 (中川, 1961) ${ }^{59}$ 又は Sanderson \& Stewart (19 61） ${ }^{61)}$ の報告による simple aceto-orcein 法を施した.

鏡検に際しては細胞核を 200〜 500個（通常 200個） 算定した. 男で 1 個以上の, 又女で 2 個以上のsex chromatin $5 \%$ 以上認めた場合洅再検查を施行した.

第 7 表 Sex Chromatin 異常者のSex Chromatin 及び性染色体構成の所見

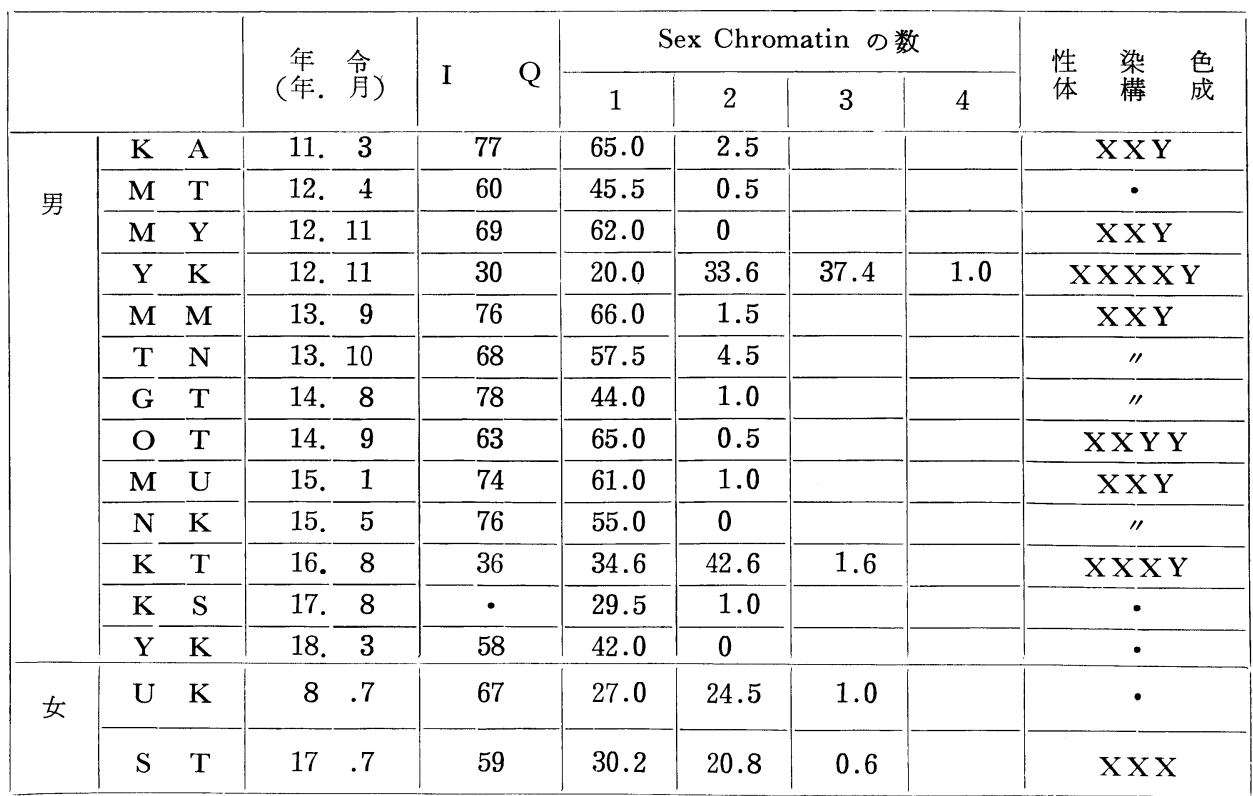

〔注】Sex Chromatin 検査は Guard 氏染色法による. 
第 3 図 Karyotype 47/XXY と One Barr Body (症例 T.N.)

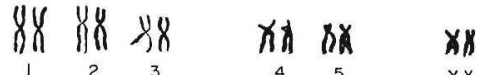

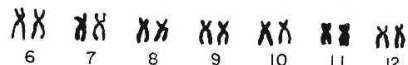

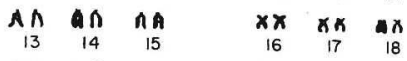

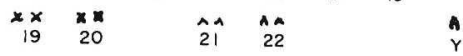

第 4 図 Karyotype 48/XXYY そ One Barr Body (症例O.T.)
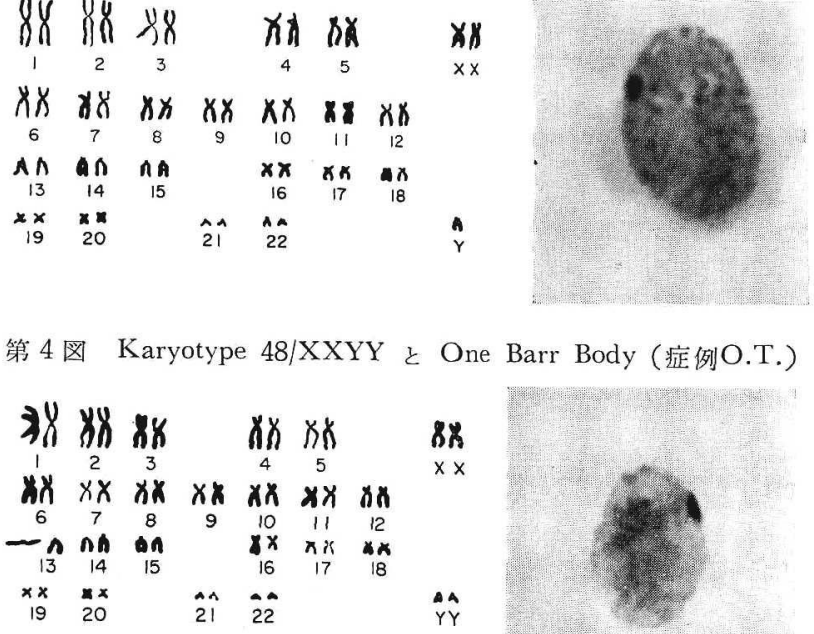

第 5 図 Karyotype 48/XXXY と Two Barr Bodies (症例 K.T.)

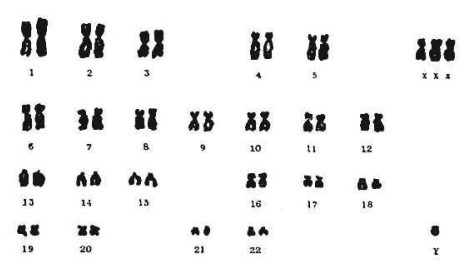

第6 図 Karyotype 49/XXXXY そ Three Barr Bodies (症例 Y.K.)

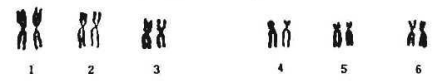

\begin{tabular}{|c|c|c|c|c|c|c|}
\hline 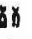 & $x K$ & $x x$ & K6 & $x$ & 88 & bax \\
\hline & 8 & 9 & ${ }^{10}$ & 11 & 12 & $\mathrm{xx} \times \mathrm{x}$ \\
\hline A & $\begin{array}{l}\text { A A } \\
14\end{array}$ & ${ }_{15}^{10}$ & & $\begin{array}{l}x: \\
16\end{array}$ & $\begin{array}{l}x x \\
17\end{array}$ & ${ }_{18}^{4.4}$ \\
\hline & $\begin{array}{l}8 x \\
20\end{array}$ & & $\hat{21}$ & $\ddot{z 2}$ & & y \\
\hline
\end{tabular}

第 7 図 Karyotype 47/XXX そ Two Barr Bodies (症例 S.T.)
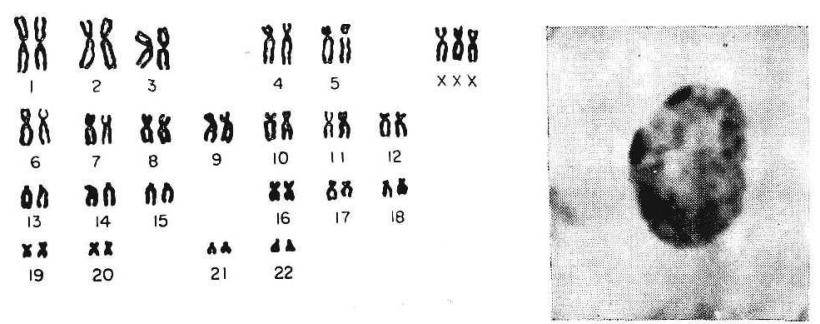
又 sex chromatin 異常者は Moorhead ら (1960) ${ }^{80)}$ の末梢血白血球培息法により染色体検査を行つた（北海 道大学理学部牧野教室に依頼して行つた。）

\section{2. 研究結果}

精薄男児 683名中13名の異常者を発見し, その異常者 の頻度は1.90\%であつた (第6表). その内訳は one Barr body 29.5〜 66.0\%に有した11例のうち染色体検查 の末施行の3 例を除けば, 7 例が性染色体構成 XXY で 他の 1 例は XXYYであつた. two Barr bodies を42.6 \%に認めた 1 例の性染色体構成は XXXYで, 又 three Barr bodies を37.4\%に認めた 1 例のそれは XXXXY であつた（第 7表，第 $3 〜 6$ 図）.精薄女児に関すれば， 515名老検查して two Barr bodies を夫々 $20.8 \%$ 及び $24.5 \%$ に有した 2 例の異常者を発見した．その異常者の 頻度は0.39\%であつた (第 6 表). そのうち1例は性染色 体構成 XXX であつたが,他の 1 例は未検査である（第 7 表, 第 7 図).

\section{3. 考 按}

Pasqualini ら (1957) ${ }^{81)}$ が Klinefelter 症候群 (sex chromatin 検査は施行されていない) を呈した31名中 11名が精薄で15例が知能指数が正常以下であつたと報告 してより, 精薄児群では sex chromatin 異常者一般大 衆より多く存在するであろろ事が当然考えられ，本邦汇

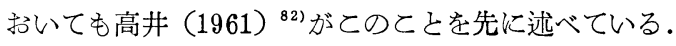
糖薄男児に対する検查は Ferguson-Smith (1958) ${ }^{83)}$ 及び Prader ら (1958) ${ }^{84)}$ の最初の報告に始まり, 現在

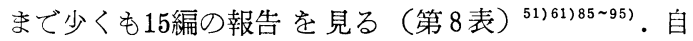
験を含めると 12,166 名に検查が施行されて 118 名の

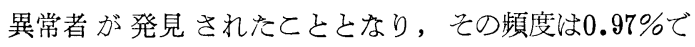
ある。これら報告の中で最も低い頻度は Hamerton ら (19.62） ${ }^{511}$ の0.44\%であり, 又最も高い頻度は Carr

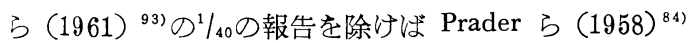
の2.39\%である. 自験の1.90\%の頻度は Prader ら（19 58） ${ }^{84)}$ に次いで高い值であり, 諸家の報告の平均頻度 $0.97 \%$ のば 2 倍の值に相当する. このととは, 本邦の 精薄男児群に抢ける sex chromatin 異常者は欧米に比 して約 2 倍の高い頻度で存在するととを意味する. sex chromatin 異常の中で最も多い型は第 8 表でも示され る様に one Barr body を有するものであり, two 又は three Barr bodies を有する個体り頻度は非常に少い上 考えられる. 又 sex chromatin 異常と I.Q. の点に関 すれば，第 7 表で示される如く自験に批いて, one Barr body を有した11例の I.Q. は58〜 78と著明な知能指数 の低下を見ないが, two 及び three Barr bodiesを有し た個体のそれは夫々 36 及び30 と強い精薄を示した。との ことより重症精薄児群より軽症精薄児群に扔ける力ぶ

第 8 表 精薄男児に於けるSex Chromatin 異常者の頻度（既報告例，\%）

\begin{tabular}{|c|c|c|c|c|c|c|c|}
\hline \multirow[b]{2}{*}{ 報 } & \multirow[b]{2}{*}{ 者 } & \multirow{2}{*}{ 検査例数 } & \multirow{2}{*}{$\begin{array}{ll}\text { 異 } & \text { 常 } \\
\text { 者 } & \text { 数 }\end{array}$} & \multicolumn{3}{|c|}{ Sex Chromatin の数 } & \multirow{2}{*}{ 頻 } \\
\hline & & & & 1 & 2 & 3 & \\
\hline Ferguson-Smith & $' 58$ & 325 & 4 & 4 & & & 1.54 \\
\hline Prader- 他 & $' 58$ & 336 & 8 & 8 & & & 2.39 \\
\hline Ferguson-Smith & $' 59$ & 663 & 8 & 8 & & & 1.21 \\
\hline Barr- 他 & '60 & 1,506 & 14 & 11 & 3 & & 0.93 \\
\hline Cornwell & 60 & 409 & 3 & 3 & & & 0.73 \\
\hline de la Chapelle- 他 & $' 60$ & 342 & 3 & 3 & & & 0.88 \\
\hline Ferguson-Smith & '60 & 916 & 9 & 7 & 2 & & 0.98 \\
\hline Mosier- 他 & ${ }^{\prime} 60$ & 1,252 & 10 & 10 & & & 0.80 \\
\hline Shapiro- 他 & 60 & 900 & 6 & 6 & & & 0.67 \\
\hline Breakey & '61 & 157 & 1 & & 1 & & 0.64 \\
\hline Carr- 他 & '61 & 40 & 1 & 1 & & & 2.50 \\
\hline Israelsohn-他 & '61 & 1,556 & 7 & 7 & & & 0.45 \\
\hline Sanderson- 他 & '61 & 245 & 2 & 2 & & & 0.82 \\
\hline Hamerton- 他 & 62 & 229 & 1 & 1 & & & 0.44 \\
\hline Maclean- 他 & '62 & 2,607 & 28 & 23 & 4 & 1 & 1.07 \\
\hline 自 験 & '65 & 683 & 13 & 11 & 1 & 1 & 1.90 \\
\hline 計 & & 12,166 & 118 & 105 & 11 & 2 & 0.97 \\
\hline
\end{tabular}


第 9 表 精薄女览に於ける Sex Chromatin 異常者の頻度（既報告例，\%）

\begin{tabular}{|c|c|c|c|c|c|c|c|}
\hline \multirow[b]{2}{*}{ 報 } & \multirow[b]{2}{*}{ 者 } & \multirow{2}{*}{ 検査例数 } & \multirow{2}{*}{$\begin{array}{ll}\text { 異 } & \text { 常 } \\
\text { 者 } & \text { 数 }\end{array}$} & \multicolumn{3}{|c|}{ Sex Chromatin の数 } & \multirow{2}{*}{ 頻度 } \\
\hline & & & & 0 & 2 & 3 & \\
\hline Fraser- 他 & 60 & 595 & 4 & & 4 & & 0.67 \\
\hline Johnston- 他 & 61 & 827 & 3 & & 3 & & 0.36 \\
\hline Sanderson- 他 & 61 & 240 & 1 & & 1 & & 0.42 \\
\hline Hamerton- 他 & 62 & 196 & 1 & & 1 & & 0.51 \\
\hline Maclean- 他 & 62 & 1,907 & 9 & 1 & 8 & & 0.47 \\
\hline Breg- 他 & 62 & 148 & 3 & & 3 & & 2.03 \\
\hline Day 他 & 64 & 1,088 & 8 & & 7 & 1 & 0.74 \\
\hline 自験 & 65 & 515 & 2 & & 2 & & 0.39 \\
\hline 計 & & 5,656 & 31 & 1 & 29 & 1 & 0.55 \\
\hline
\end{tabular}

第10表 新生览に於ける Sex Chromatin 異常者の頻度（\%)

\begin{tabular}{|c|c|c|c|c|c|c|c|c|}
\hline & \multirow{2}{*}{ 報 } & & \multirow{2}{*}{ 検查例数 } & \multirow{2}{*}{$\begin{array}{ll}\text { 異 } & \text { 常 } \\
\text { 者 } & \text { 数 }\end{array}$} & \multicolumn{3}{|c|}{ Sex Chromatin の数 } & \multirow{2}{*}{ 頻 } \\
\hline & & & & & 0 & 1 & 2 & \\
\hline \multirow{4}{*}{ 男 } & Moore & $' 59$ & 1,911 & 5 & & 5 & & 2.67 \\
\hline & Bergemann & '61 & 1,890 & 4 & & 4 & & 2.12 \\
\hline & Maclean 他 & 64 & 10,725 & 21 & & 21 & & 1.96 \\
\hline & 計 & & 14,526 & 30 & & 30 & & 2.07 \\
\hline \multirow{4}{*}{ 女 } & Moore & '59 & 1,804 & 0 & & & & 0 \\
\hline & Bergemann & '61 & 1,838 & 1 & 1 & & & 0.54 \\
\hline & Maclean 他 & '64 & 10,000 & 16 & 4 & & 12 & 1.60 \\
\hline & 計 & & 13,642 & 17 & 5 & & 12 & 1.25 \\
\hline
\end{tabular}

sex chromatin 異常者が多く存在するととが考えられ る. Prader ら $(1958)^{84)}$ 及び Ferguson-Smith $(1959)^{83)}$ の頻度は夫ネ 2.39 及び $1.21 \%$ と高いが，検查対象者の I.Q. を見ると前者では75～85，後者では45〜85であつ たし，自験に掞いても I.Q.が殆んぞ60〜80を示した特

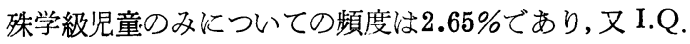
が多くは60以下を示した精薄施設の児童の及についての それは1.17\%であつたととは上述したととに基づくと解 釈される。

精薄女児に関すれば Fraser ら (1960) ${ }^{96)}$ の最初の報 告に始まり，現在まで少くも 7 編の文献を見る（第 9 表) ${ }^{51) 61195) 97 ~ 991}$. 自験例数含含めると, 5,656 名が検查 されて31名の異常者が発見されたとととなり，その頻度 は0.55\%となる．自験の $0.39 \%$ はこれに比較して，やや 低い值を示している。

一方，一般大衆に抢ける sex chromatin 異常者の頻 度については Moore $(1959)^{100)}$, Bergemann $(1961)^{101}$ 及び Maclean ら $(1961 ， 1964)^{1021103)}$ の新生児を対象
とした報告があり，とれらの結果を合わせると男では 14,526 名中 30 名の異常者 (いずれも one Barr body を有する異常）が存在することとなり，その頻度は 2.07 11,000 となる. 又女では 13,642 名中 17 名の異常者 (chromatin-negative，5名：2 Barr bodies，12名）が 発見されており，その頻度は $1.25 / 1,000$ となる（第10 表).との頻度を精薄児群のそれと比較すると約 $1 / 5$ の頻度 に相当する. 即与新生児群の頻度をそのまま一般大衆の 頻度と見做すなら，精薄児群では一般大衆よりも約 5 倍 の高い頻度で sex chromatin 異常者が存在することと なる. 本邦における新生児群の異常者頻度は検索されて いない，自験の精薄坚群の)異常者頻度が欧米の諸家の平 均頻度に比較して男では約 2 倍並びに女では大差ない值 を示したととょり, 本邦に打りる一般大采の sex chromatin 異常者の頻度は男では 欧米に拈ける頻度 $2.07 /$ 1,000 よりかなり高いであろうと推測され, 女では欧米 に扔ける頻度 1.25/1,000 とほぶ同じであろろと思われ る. 
次いで私の発見した15例中染色体検查を施行した11例 に関してその sex chromatin と性染色体構成の所見を 観察するに, 男で sex chromatin を1個, 2 個及び 3 個有した症例ではX染色体を夫々 2 個, 3 個及び 4 個と 有し, 又女で 2 個の sex chromatin 有した症例では 3 個のX染色体を有していた。このことは第 1 編で既述し た sex chromatin の数はX染色体の数より常に 1 を減 じた数に相当するとの所謂 sex chromatin の単一X染 色体説に合致すると共に，1個のX染色体定除いた他の $\mathrm{X}$ 染色体は機能的に不活性化されており，乙れが休止期 核に於いて sex chromatin を形成するとの Ohno ら (1961） ${ }^{24)}$ の説汇実証的裏付けを与えるものである.

更に私は本編の研究に抬いて sex chromatin の所見 よりその性染色体構成を十分に予測可能であつたことは sex chromatin の screening method としての価值を実 証したとととなり, 又染色体検査が高度の設備及び経験 が要求される現在では sex chromatin 検查法は一般臨 床検査法として全く有用であることに確認を与えるもの であつた。しかしながら XXYY 症例の如くY染色体の 過剩及び本編の研究では発見されなかつたが mosaic の 存在は sex chromatin の所見では知ることが出来ず, 染色体分析をまたなければならない故, 可及的染色体検 查も sex chromatin 検查と共に施行されることが望ま しいととは云うまであない.

\section{4. 結 語}

1).精薄男児 683 名及び女児 515 名に対して sex chromatin 検查法を施行し, 男13名, 及び女 2 名の異常者 を発見した，その異常者の頻度は男 $1.90 \%$ 及び女 $0.39 \%$ であつた。この值は欧米の諸家の報告による平均頻度に 比して男では約 2 倍の高値に相当し, 女では大差ない值 であつた。

2). 本邦に招ける一般大衆の sex chromatin 異常者 の頻度は1)の結果及び文献考察より男では 欧米の頻度 2.07/1,000 よりかなり高い頻度が予測され，又女では 1.25/1,000 と添ざ大差ないものの様に推測された.

3). 発見した sex chromatin 異常者15例中, 染色体 検查を施行した11例についてその sex chromatin の所 見と性染色体構成の関係を見るに，第 1 編で既述した sex chromatin の単一X染色体説任実証的裏付けを与え るものであつた.

4). sex chromatin の所見よりその性染色体構成が十 分に推測可能であつたととは, screening method とし ての sex chromatin 検査法の意義に確証を与えるもので
あつた。

第 5 編 性染色体構成異常症例の臨床像に関する検討

人の性は受精時に決定される. 即ち正常男女に扮いて はその性染色体構成が XY であるか又は XX であるか によつて性腺原基の䯣質が発育して皁丸となるか, 皮質 が発育して卵巣となるかが決定されるわけであり, 故に 性染色体構成の異常は性の決定及び性分化何らかの影 響を与えるであろろ事は当然考えられるところである。 性染色体構成異常症例は Jacobs ら (1959) ${ }^{14) 104)}$ の XXY 及び XXX 型の最初の報告に始まり現在まで性染 色体の数的異常及び mosaic 型など数多くの報告を見る が, 最近これら異常例の臨床所見を蒐集して性染色体と 性決定及び性分化とり関係が論じられ様としている。

当教室に於いて1960年より約 5 年間に性染色体構成異 常症例を23例経験している. 私はこれら症例についてそ の臨床的, 細胞学的, 性腺の組織学的及び内分泌学的所 見を研究し, 性染色体構成異常と性決定及び性分化との 関係について考察を試みた。 な招 XXY 型の 2 例 ( Takai ら, 1962) ${ }^{105)}$, XXYY 型の 1 例 (高井ら, 1965 : Takagi ら, 1965) ${ }^{106) 107)}$, 更に XXXXY, XXXY, $\mathrm{XXX}, \mathrm{XO} / \mathrm{XY}$, 及び $\mathrm{XY} / \mathrm{XXY}$ 型の各 1 例（高井ら, 1964（ ${ }^{15)}$ についての詳細な臨床像の検討 は先に報告し ている. 又第 4 編の研究で発見された15例中, 男で one Barr body を有した 3 例及び女で two Barr bodies 有した1例については, その染色体検查が未施行の故, 本編の研究に於いては除外した。

\section{1. 研究症例}

性染色体構成異常を呈した23例の内訳は男で数的異常 を示した20例 (XXY 型17例, XXYY 型 1 例, XXXY 型 1 例, 及び $\mathrm{XXXXY}$ 型1例）と mosaic の 2 例 ( $\mathrm{XO} / \mathrm{XY}$ 型 1 例, $\mathrm{XY} / \mathrm{XXY}$ 型 1 例), 女で数的異常 を示した 1 例 (XXX 型)である. 又性異常を訴えて札 幌医科大学泌尿器科淁訪れた症例は $\mathrm{XXY}$ 型の10例及 び mosaic 型の 2 例で, 他の11例は第 4 編の研究により 発見された症例である。

\section{2. 研究方法}

i. 細胞学的検查 : sex chromatin 検查は buccal smear を材料として aceto-orcein 法 (Sanderson \& Stewart；1961） ${ }^{61)}$ 又は Guard 法の変法 (中川, 1961) ${ }^{59)}$ を施行して, 各標本につき 100〜 500個（通常 200個） の細胞核を算定して, 第 3 編で既述した判定基準に従つ た. 染色体検查汹胸骨穿刺で得られた細胞を用いた（Ford ら，1958（ ${ }^{108)} 2$ 例を除けば, 他は全例が末梢血液白 
血球培養法（Moorhead ら，1960） ${ }^{80)}$ を用いた。

ii. 臨床的検查

a. 睪丸, 副㫱丸及び 精管 : 睪丸生検の 際に観察し た．睪丸の大きさはその長軸の測定值で示した．

b. 前立腺 : 直腸診によりその大きさを触れ難い (0), 正常以下 (1)及び正常（2）纪分類した。

c. 抄毛: 発毛がない(0), 非常に粗 (1), 粗 (2), やや粗（3），及び正常男性型（4）と分類した.

d. 知能指数は主に田中 Binet 式又心鈴木 Binet 式検 查法を用い，色盲検查以石原式色盲表を用いた。

なおa〜cの所見及び陰蕉, 陰囊の所見については，そ の検查方法上，客観性に乏しいのは止むを得なかつた。

iii. 尿中ホルモン測定 : 24 時間尿について検查し通常 3 日間連続測定した。

a. gonadotrophin: Brodbury 変法 (松島, 1962) ${ }^{109)}$

によつた。その男での正常值は14才以下は 6 単位以 下, 14〜50才で12〜24単位, 去勢群では48〜 192単位で ある。

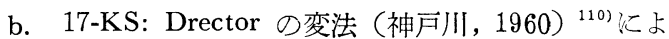

つた. その男に扮ける正常值は $9 \sim 13$ 才： $0.3 \sim 2 \mathrm{mg}$, 13〜18才：1〜 $5 \mathrm{mg}$ ，18〜 60才：4〜 $8 \mathrm{mgC゙ある.}$

c. 17-OHCS: Glenn \& Nelson の変法（神戸川,

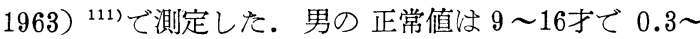
1.5mgであり, 17〜60才で 1〜 $3 \mathrm{mg}$ あるる.

d. estrogen: Brown の変法（神戸川, 1961） ${ }^{112)} \mathrm{K}$ よつた 男の正常值は 8〜18才で 0〜 $5 \mu \mathrm{g}, 19$ ～60才で $2 \sim 10 \mu \mathrm{g}$ である.

iv，睪丸の組織学的㭘查 : 本検查は教室の佐々木の研 究によるが, それによると男の全例に章丸生検が施行さ れ，1 側のみ生検の 2 例を除いた他の症例では両側の生 検が施行されている。組織標本は hematoxylin and eosin 染色, Sudan III 染色及び azan 染色法が施行さ れた。精細管の萎縮硝子化変性の程度は全く見られない (一), 少数の精細管に見られる(十), 約半数の精細管に 見られる(H), 及び殆んごの精細管に見られる (卅), ものに分類され，又 Leydig 細胞については正常範团に 見られるもの (十), 及び異常な增加を示すもの $(H)$, に分けて観察している。

第11表 細胞学的及び遺伝学的所見（男の数的異常20例）

\begin{tabular}{|c|c|c|c|c|c|c|c|c|c|c|c|c|c|c|c|}
\hline \multirow{3}{*}{ 症＼cjkstart例 } & \multirow{3}{*}{ 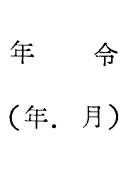 } & \multirow{3}{*}{$\begin{array}{l}\text { 同胞に } \\
\text { 打樯る } \\
\text { 竝置 }\end{array}$} & \multicolumn{2}{|c|}{ 生下時の } & \multicolumn{3}{|c|}{ Sex Chromatinの数 } & \multicolumn{8}{|c|}{ 染 色 体 検 査 } \\
\hline & & & \multirow{2}{*}{$\begin{array}{l}\text { 母の } \\
\text { 年令 }\end{array}$} & \multirow{2}{*}{$\begin{array}{l}\text { 父の } \\
\text { 年令 }\end{array}$} & \multirow{2}{*}{1} & \multirow{2}{*}{2} & \multirow{2}{*}{3} & \multicolumn{6}{|c|}{ 染色体数 } & \multirow{2}{*}{ 算定 } & \multirow{2}{*}{ 核 } \\
\hline & & & & & & & & $<46$ & 46 & 47 & 48 & 49 & $49<$ & & \\
\hline 1. $\mathrm{KA}$ & 11. 3 & $2 / 5$ & 24 & 30 & 65.0 & & & & 2 & 24 & & & & 26 & 47/XXY \\
\hline 2. MY & 12. 11 & $2 / 3$ & 36 & 41 & 62.0 & & & & 1 & 40 & & & & 41 & 11 \\
\hline 3. $\mathrm{YK}$ & 12. 11 & $1 / 2$ & 21 & 25 & 20.0 & 33.6 & 37.4 & & & & 2 & 100 & 3 & 105 & $49 / \mathrm{XXXXY}$ \\
\hline 4. $\mathrm{MM}$ & 13. 9 & $1 / 2$ & 19 & 28 & 66.0 & & & & 3 & 36 & 1 & & & 40 & $47 / \mathrm{X} X \mathrm{Y}$ \\
\hline 5. $\mathrm{T} \mathrm{N}$ & 13. 10 & $2 / 4$ & 32 & 40 & 57.5 & & & 1 & & 38 & 1 & & & 40 & " \\
\hline 6. G T & 14: 8 & $6 / 6$ & 49 & 55 & 44.0 & & & & 2 & 39 & & & & 41 & " \\
\hline 7. $\mathrm{OT}$ & 14. 9 & $4 / 4$ & 38 & 39 & 65.0 & & & & & 3 & 37 & & & 40 & $48 / X X Y Y$ \\
\hline 8. MU & 15. 1 & $2 / 4$ & 25 & 29 & 61.0 & & & & & 28 & & & & 28 & $47 / \mathrm{X} X \mathrm{Y}$ \\
\hline 9. NK & 15.5 & $1 / 1$ & 23 & 28 & 55.0 & & & & 3 & 40 & & & & 43 & "I \\
\hline 10. $\mathrm{K} \mathrm{T}$ & 16. 8 & $6 / 6$ & 45 & 45 & 34.6 & 42.6 & & & & 1 & 96 & 3 & & 100 & $48 / \mathrm{XXXY}$ \\
\hline 11. I M & 17. 1 & $6 / 7$ & 34 & 42 & 57.0 & & & 1 & 2 & 12 & & & & 15 & $47 / \mathrm{XXY}$ \\
\hline 12. $\mathrm{T} \mathrm{Y}$ & 20. 5 & $3 / 4$ & 29 & 38 & 72.5 & & & & & 34 & 1 & & & 35 & " \\
\hline 13. $\mathrm{YA}$ & 21. 4 & - & - & $\cdot$ & 45.0 & & & & 1 & 31 & & & & 32 & " \\
\hline 14. $\mathrm{Z} \mathrm{S}$ & 25.9 & $4 / 7$ & 30 & 35 & 67.0 & & & & 2 & 60 & 1 & & & 63 & 11 \\
\hline 15. S O & 28. 4 & $6 / 6$ & 36 & 43 & 44.0 & & & $\overline{1}$ & 1 & 27 & & & & 29 & " \\
\hline 16. $\mathrm{MN}$ & 28. 6 & $1 / 2$ & 37 & 49 & 64.5 & & & & & 13 & & & & 13 & $" \prime$ \\
\hline 17. $\mathrm{K} \mathrm{T}$ & $29 . \quad 2$ & $1 / 6$ & 21 & 25 & 47.5 & & & & 1 & 49 & & & & 50 & 1 \\
\hline 18. $\mathrm{MN}$ & 30. 11 & $6 / 6$ & • & ${ }^{\circ}$ & 47.0 & & & 1 & 2 & 15 & 1 & & & 19 & "1 \\
\hline 19. $\mathrm{NN}$ & 33. 5 & ${ }^{10} / 10$ & 49 & 55 & 52.5 & & & 1 & & 58 & & & 1 & 60 & " \\
\hline 20. N S & 36. 10 & $3 / 8$ & 22 & 26 & 58.0 & & & & 1 & 51 & 1 & & & 53 & $" 1$ \\
\hline
\end{tabular}




\section{3. 研究結果}

i. 男の数的異常の 20 例に関して

a. 細胞学的及び遗伝学的所見 : 第11表に示されろ如 く20例全てが sex chromatin 陽性であつた. one Barr body が44.0〜 72.5\%の頻度で認められた18例のうち17 例の性染色体構成は XXY 型であり，他の 1 例の核型は 48/XXYY であつた. two Barr bodies を42.6\%に有し た症例の核型は $48 / \mathrm{XXXY} て ゙$, 㕛 three Barr bodies

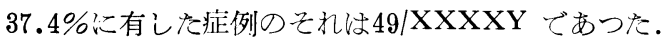

患者の同胞汇於ける位置を見ると19例中 6 例犬゙末子で ある. 又18例の患者出生時の母の平均年令は31.7才で, 札幌市の 1963 年の平均年令 26.6 才と比較すれば 5 年も高 率となる。父のそれは18例に関して37.4才であつた。

\section{b. 臨床的所見（第12表）}

箤丸の大きさは11〜13才（思春期又はそれ以前）の 4

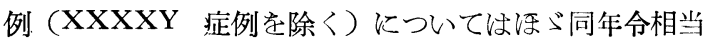
の大きさを有したが，他の思春期以後の15例では15〜25 $\mathrm{mm}$ と著明な萎縮を呈した. 精管に関して㹥, 正常 8 例, 正常より細いものが 6 例であつた，前立線は正常に触れ たものが 2 例で，正常より小であるものが 6 例及び触れ 難いものが 9 例であつた。な扮副宰丸は全例正常であつ た. 陰莖は正常が 16 例, やや短小 3 例, 及び短小 1 例で

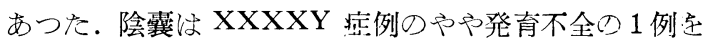
除けば他の全例が正常であつた。恥毛関しては，発毛 の全く認めないものは 8 例 (13才以下が5例含まれる), 極く粗 2 例, 粗 3 例, やや粗 2 例, 及び正常男性型を呈 したものは 5 例であつた.

知能指数は XXY 型15例及び XXYY 型 1 例について 見ると59〜 100で90 以上を示したものが5例いたが， $\mathrm{XXXY}$ 及び XXXXY 症例では夫々 36 及び 30 と著明な 低下を示した。

女性型乳房症は 3 例 $(15.0 \%)$ に見られたが15才以上 のものについていうと $23.1 \%$ となる.

身長について見るに，19例中 2 例安除けばいずれも19 60 年日本人男子平均值より長身を示して扮り, 又体重で は 25 才未満の痖例では 1960 年日本人男子平均值上り低值 を示すものが多かつた（第8図）.

主訴を見るに11〜16才の 10 例は第 4 編の精薄児群を検 査して発見した症例であるが，他の10例に関すれば女性 型乳房症 2 例, 無耽毛症 1 例, 陰莝短小 2 例, 不妊 2 例, 性生活の障害 2 例及び血尿 1 例であつた。血尿の 1 例は尿路結石症で来院した患者であつた。

性生活に関すると, 早朝勃起のあるもの $4 / 8$, 自賏
第 8 図 男の数的異常 20 例の身長及び体重
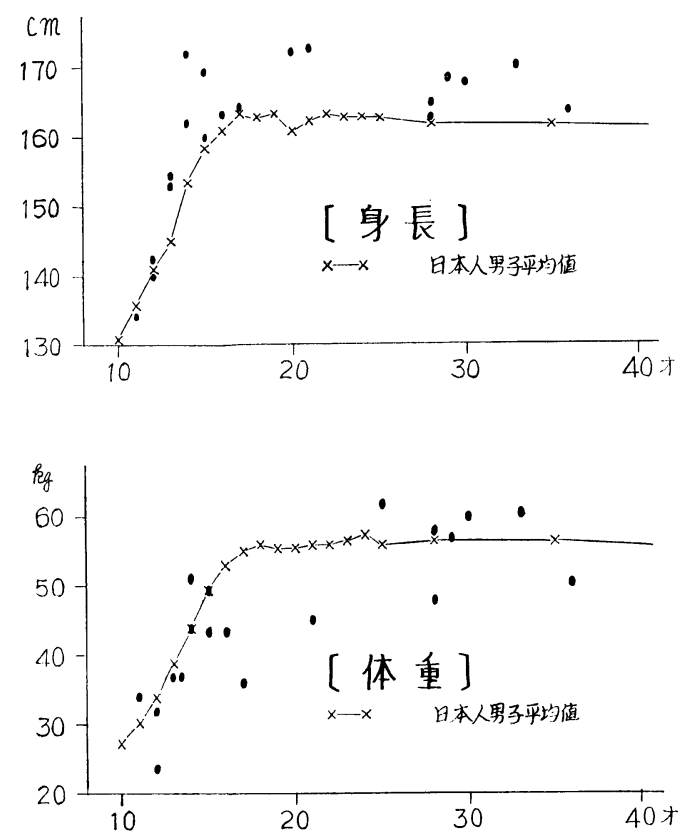

の経験あるもの $3 / 7$, 性慾の正常に存在すると云うも

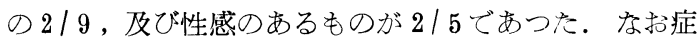
例14〜20の 7 名は既婚者であつた。

色覚異常は検查した16例では全て正常であつた。内㫮 贅皮は 5 例に，第 5 指弯指症は 3 例に，又停留睪丸及び 発育不全腎を各 1 例㹸た。

c. 内分泌学的所見 (第13表)

gonadotrophin अ症例12では 6 単位以下と低值を示し たが，他の19例ではいずれも正常值より高值を示した。 症例1,2では12単位以下と軽度の上界を見たに過ざない が，他の例では全て非常な高値を呈した。

17-KS については10例が正常值を示し．正常〜高値 4 例, 高值 3 例及び低值を示すものが 3 例であつた.

17-OHCS は14例について検査されたが, 症例17が低 值を示した他は全て正常ないしは高值を示した。

estrogen 结測定された 10 例中 3 例が正常值を示した が，他の 7 例は高值を示した，

d. 睪丸の組織学的所見 (第13表)

教室佐々木の研究によると次の如くである. 症例 1,2 （11１2才）では精細胞の萎縮硝子化は全くなくその管 径は思春期初期相当に発育して抢り，管内細胞は大部分 が未分化細胞よりなり精祖細胞の存在するのは少数の精 細管にすぎなかつた，かつ精細管壁の肥厚は全く認めな 
第12表 臨床的所見（男の数的異常 20 例）

\begin{tabular}{|c|c|c|c|c|c|c|c|c|c|c|c|c|c|}
\hline \multirow{2}{*}{ 症例 } & \multirow{2}{*}{$\begin{array}{l}\text { 知能 } \\
\text { 指数 }\end{array}$} & \multirow{2}{*}{$\begin{array}{l}\text { 女性型 } \\
\text { 乳房症 }\end{array}$} & \multirow{2}{*}{${ }^{-}(\mathrm{cm})^{\text {長 }}$} & \multirow{2}{*}{ (kg) } & 辠 & 丸 & \multirow{2}{*}{ 恥毛 } & \multirow{2}{*}{ 陰茎 } & \multirow{2}{*}{ 陰囊 } & \multirow{2}{*}{ 副悬丸 } & \multirow{2}{*}{ 精管 } & \multirow{2}{*}{ 前立腺 } & \multirow{2}{*}{ 主 } \\
\hline & & & & & 右 & 左 & & & & & & & \\
\hline 1 & 77 & - & 134.0 & 34.0 & 24 & 25 & 0 & $\mathrm{~N}$ & $\mathrm{~N}$ & $\mathrm{~N}$ & $\mathrm{~N}$ & 0 & $\begin{array}{l}\text { 精薄児 } \\
\text { screening }\end{array}$ \\
\hline 2 & 69 & - & 140.0 & 32.0 & . & 23 & 0 & " & "I & "I & "I & 2 & " \\
\hline 3 & 30 & - & 142.0 & 23.5 & 13 & 13 & 0 & " & $\begin{array}{l}\text { や良全 } \\
\text { 等 }\end{array}$ & "I & " & 0 & "I \\
\hline 4 & 76 & - & 154.5 & 37.0 & 24 & 25 & 0 & " & $\mathrm{N}$ & "I & "I & 0 & " \\
\hline 5 & 68 & - & 153.0 & 37.0 & 29 & 28 & 0 & " & "I & "I & " & 0 & " \\
\hline 6 & 78 & - & 172.0 & 51.0 & 25 & 25 & 1 & " & "I & "I & $\begin{array}{l}\text { 細 } \\
\end{array}$ & 1 & " \\
\hline 7 & 63 & - & 162.0 & 44.0 & 17 & 19 & 0 & " & "I & "I & $\mathrm{N}$ & 0 & " \\
\hline 8 & 74 & - & 160.0 & 43.0 & 20 & 20 & 0 & " & " & " & 細 & 1 & " \\
\hline 9 & 76 & - & 169.5 & 49.5 & 22 & 22 & 4 & "1 & " & "I & " & 2 & " \\
\hline 10 & 36 & + & 163.0 & 43.0 & 22 & 25 & 1 & $\begin{array}{l}\text { やや } \\
\text { 短小 }\end{array}$ & " & " & $\mathrm{N}$ & 0 & " \\
\hline 11 & 90 & + & 164.0 & 36.3 & 18 & 19 & 4 & $\mathrm{~N}$ & " & " & • & • & 女性型乳房症 \\
\hline 12 & 90 & + & 172.0 & - & 15 & 16 & 3 & " & " & " & 細 & 1 & " \\
\hline 13 & 59 & - & 173.0 & 45.0 & 18 & 17 & 0 & "1 & " & "1 & $\mathrm{N}$ & 0 & 無恥毛 \\
\hline 14 & - & - & - & 62.0 & 20 & 18 & 2 & $\begin{array}{l}\text { やや } \\
\text { 短小 }\end{array}$ & " & " & - & 0 & 隍茎短小 \\
\hline 15 & 83 & - & 163.0 & 48.0 & 17 & 16 & 3 & 短小 & "I & "1 & 細 & 0 & "1 \\
\hline 16 & 59 & - & 165.0 & 58.0 & 20 & - & 4 & $\mathrm{~N}$ & " & " & - & 1 & 不妊 \\
\hline 17 & - & - & 168.5 & 57.0 & 20 & 17 & 2 & $\begin{array}{l}\text { やや } \\
\text { 短小 }\end{array}$ & " & " & - & 1 & $\begin{array}{l}\text { 性:生活 } \\
\text { の障害 }\end{array}$ \\
\hline 18 & 92 & - & 168.0 & 60.0 & 18 & 16 & 4 & $\mathrm{~N}$ & "1 & " & - & - & "1 \\
\hline 19 & 100 & - & 170.5 & 60.5 & 15 & 16 & 2 & " & "1 & "1 & 細 & 1 & 不妊 \\
\hline 20 & 95 & - & 164.0 & 50.0 & 20 & 15 & 4 & " & " & "1 & 1 & - & 血尿 \\
\hline
\end{tabular}

第 9 図症例 2 (M.Y.) の啇丸組織像, 精上皮細 胞の極度の減少を除いては特に所見がない

(hematoxylin and eosin 染色, × 100)

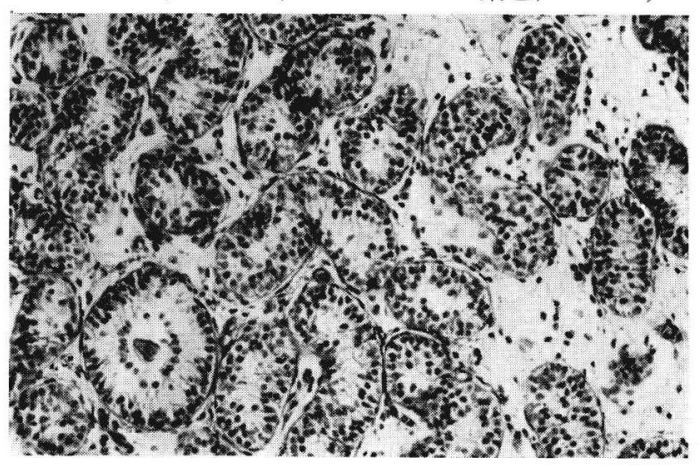

かつた. 間質は Leydig 細胞が少数の小集団をなして字 在し同年令相当の所見学呈した（第 9 図）.

症例 3〜 5（12〜13才）では，精細管、完全な萎縮硝

子化走示子ものから年令相当の正常発育走示立ものまで
第10図 症例 4 (M.M.) の鐼丸組織像，管壁の肥 厚が著明で一部の精細管は完全に萎縮硝子 化を呈する（azan 染色，×100）

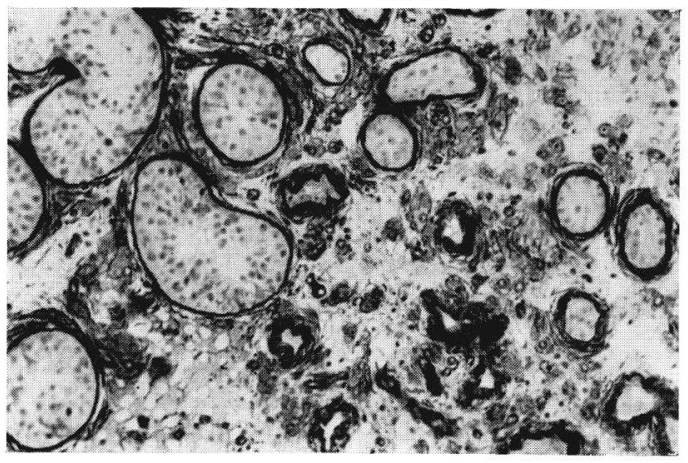

変化に富み, 従つて管壁も肥厚の著明なものから正常の ものなで見られた，管内細胞は殆んどが未分北細胞であ り，こくく一部の精細管にのみ精租細胞が認められた。間 質の Leydig 細胞は数学增しているか, 病的な程度に㤃 
第13表 内分泌学的及び辠丸の組織学的所見（男の数的異常20例）

\begin{tabular}{|c|c|c|c|c|c|c|}
\hline 症例 & $\begin{array}{c}\text { F.S.H. } \\
\text { (muu/day) }\end{array}$ & $\begin{array}{c}17-\mathrm{KS} \\
\text { (mg/day) }\end{array}$ & $\begin{array}{r}\text { 17-OHCS } \\
\text { (mg/day) }\end{array}$ & $\begin{array}{l}\text { Estrogen } \\
(\mu \mathrm{g} / \text { day })\end{array}$ & $\mid \begin{array}{l}\mid \text { 精細管の硝子萎 } \\
\text { 子 }\end{array}$ & $\begin{array}{l}\text { Leydig } \\
\text { 細 胞 }\end{array}$ \\
\hline 1 & $8-12$ & 1. $14-2.0$ & $1.91-2.30$ & $30.60-57.10$ & - & + \\
\hline 2 & $<12$ & $1.50-6.22$ & $1.10-2.25$ & $9.20-44.0$ & - & + \\
\hline 3 & $6 \rightarrow>48$ & $1.45-4.38$ & $1.30-2.56$ & $1.30-6 . C 0$ & + & + \\
\hline 4 & $>48$ & $2.16-4.52$ & $1.24-1.55$ & • & + & + \\
\hline 5 & $>48$ & $5.21-6.07$ & $1.15-2.88$ & - & + & + \\
\hline 6 & $>64$ & 1.44 & 1.87 & 19.38 & m & H \\
\hline 7 & $>48$ & $2.27-4.28$ & $0.918-3.54$ & - & m & H \\
\hline 8 & $>48$ & $3.42-3.52$ & $2.65-2.93$ & $10.56-35.90$ & $\pi$ & $H$ \\
\hline 9 & $>92$ & $3.79-5.49$ & $2.31-4.20$ & $24.30-48.00$ & m & H \\
\hline 10 & $>48$ & $4.50-5.94$ & $0.69-2.99$ & $8.0-11.28$ & $\mathrm{WH}$ & H \\
\hline 11 & $>48$ & 1.26 & $\cdot$ & - & m & H \\
\hline 12 & $<6$ & 正 常 & - & - & $\mathrm{m}$ & H \\
\hline 13 & $>\overline{48}$ & $6.41-7.92$ & $1.67-3.23$ & $2.05-12.48$ & m & H \\
\hline 14 & $>48$ & 正 常 & - & $38.38-39.97$ & $\mathrm{H}$ & H \\
\hline 15 & $>48$ & 2.62 & - & - & m & $\bar{H}$ \\
\hline 16 & $>192$ & 12.60 & 5.78 & - & $\mathrm{H}$ & H \\
\hline 17 & $24-48$ & $2.85-4.06$ & $0.38-0.85$ & $1.20-12.48$ & m & \# \\
\hline 18 & 80 & 3.86 & - & $\cdot$ & $\mathrm{WH}$ & $H$ \\
\hline 19 & $>128$ & 10.20 & 8.67 & - & \# & H \\
\hline 20 & $>48$ & 正 常 & $\boldsymbol{\theta}^{\circ}$ & - & $\mathrm{m}$ & \# \\
\hline
\end{tabular}

見られなかつた（第10図）.

症例 6 １0（14～16才）に执いては，精細管の大多数 壮完全涹縮硝子化を示している. 少数の硝子化を免れ た精細管は殆んどが Sertoli 細胞よりなり，一部のもの 飞精祖細胞が見られるのみであつた。間質の Leydig 細 胞々明らかな増加を示し，島状の集塊をなしているもの も見られた。

症例11〜20（17〜36才）では，殆んど全ての精細管况 完全な萎縮硝子化を示し，管内細胞は成熟した Sertoli 細胞が殆んどであるが稀には精粗細胞も見られた。間質 は Leydig 細胞が著明な增加を示し, 島状の集塊が多く 見られた。

な怙症例 9 及び19では，一部の精細管ではあるが精子 形成が認められた. 即ち精上皮の完全な分化成熟があり, ，精子も存在していた。

ii. 男の mosaic 型の 2 例関して.

a. XY/XXY 症例，54才 (高井万，1964） ${ }^{15)}$.

細胞学的及び遗伝学的所見：sex chromatin は 200 個 の細胞を算定して 1 個む見られなかつた。染色体検查は 末梢血液培養法を用い, 細胞61個を教えて染色体数 47 の 細胞が16個，46の細胞が39個，45の細胞が 6 個であつた
が染色体数 45 の細胞 6 個梌查つ操作過程に生じたもの 之判断され, 本症例の核型は染色体数 ${ }^{46} / 47$, 性染色体構成 $\mathrm{XY} / \mathrm{XXY}$ と診断された. 患者出生時の母の年令は 35 才，父の年令は 40 才で，同胞 10 人の第 7 子である.

臨床的所見 : 知能の低下完られない, 女性型乳房に 対する手術瘢痕を見る。身長 $144.5 \mathrm{rm}$, 体重 $55.0 \mathrm{~kg}$. 等 丸の長軸江右 $30 \mathrm{~mm}$, 左 $25 \mathrm{~mm}$ で, 陰莖短小, 恥毛粗, 前立 腺小であるも副等丸及で陰囊は正常であつた。

尿中ホルモン測定 : 17-KS $2.7 \mathrm{mg} / \mathrm{day}, 17-\mathrm{OHCS} 3.8$ $\mathrm{mg} /$ day, estrogen $6.8 \mu \mathrm{g} / \mathrm{day}$, gonadotrophin 6 単位以 下/day

睪丸の組織学的所見 : 精細管は著明な萎縮を示し, 管 内細胞は一層の未分化の精上皮細胞よりなり, 基底膜の 肥厚は明らかでなかつた。 間質に Leydig 細胞を認め得 なかつた。

b. XO/XY 症例, 6 才，(高井万 1964） ${ }^{15)}$

細胞学的及び遣伝学的所見: sex chromatin は 200 の 細蚫中 1 個も見られなかつた。染色体検査は 100 個の核 を教えて染色体数 45 の核は19個 46 の核は79個で, 本症 例の核型は染色体数 $45 / 46$, 性染色体構成 XO/XY の mosaic と診断された。患者生下時の父母の年令は夫く 31 
才及び 26 寸で，同胞 4 人中第 3 子である.

臨床的所見: 知能の低下はなく, 身長 $109.0 \mathrm{~cm}$, 体重 $18.0 \mathrm{~kg}$. 翼状頝 (一). 陰茎の発育要〉陰囊注 2 分化され 丁度大陰唇の如き外観を呈し, その下方に外尿道口が開 いている. 試験開腹により腟, 子宮及び卵管様索状物を 認めその終末部に左側の及性腺を認めた。

尿中ホルモン測定 : 17-KS 2.7 2.9mg/day, estrogen 19.12 28 $\mu \mathrm{g} / \mathrm{day}$, gonadotrophin 6 絆. 位以下

性腺の組織学的所思: 性腺は睪丸の組織像を呈した。 年令相当の所見を呈し病的所見は認めなかつた。

iii 女の数的異常の 1 例に関して

XXX 症例，17才 (高井ら，1964） ${ }^{15)}$

細胞学的及び遣伝学的所見: sex chromatin の細胞核を算定して 2 Borr bodies 有する核を20.8\% 汇認めた。染色体検查は50個の核について観察し, 染色 体数 47 の核は 47 個，46の核は 3 個であつた．以上上り本 症例の核型は $47 / \mathrm{XXX}$ 之診断された。患者生下時の母 の年令は 28 才, 父の年令は不明で, 患者は同胞 4 人中第 1 子である。

臨床的所見: I.Q.59. 身長 $146.0 \mathrm{~cm}$, 体重 $34.5 \mathrm{~kg}$. 乳 房は同年令の女性汇比してやや発育不全を呈した．外陰 部汇刵毛の発育不全を除いては全く正常の女性と異なる 所がなかつた. 内誩にて腟長正常, 子宮は小さかつた, な抢患者は 13 才に初潮を認め現在に至るまで月経を規則 正しく認めている。

尿中ホルモン測定及び性腺の組織学的検查は未施行で ある。

\section{4. 考 按}

i. 性染色体構成異常の成因

精子形成及び卵子形成過程に抢ける性染色体の不分離 （non-disjunction）により, 又受精卵の初期卵割時に於 ける不分離又沙欠損により種々の性染色体構成の数的異 常及び mosaic 型の個体が考えられる.

配偶子形成過程に於ける不分離の要因は不明である が，21番目染色体の trisomy を有する Down 症候群に 捻いて患者出生時り母親の多くが高命であつたてとが知 られている113). Ferguson-Smith ら (1964) ${ }^{114)}$ は sex chromatin 陽性の 45 例の男で, 出生時の母親の年令が一 般大衆より 4 年高令であつたと報告している. 自験にて も数的異常を示した18例の男に関すれば，患者出生時の 母親の年令が一般大衆のそれょりも5 年高令であつたと と注，配偶子形成過程に於ける性染色体の不分離と何ら 汃関係があると思われ注目される。 ii. 性染色体々 sex chromatin

性染色体の数的異常を示した自験 21 例について見ると 第11表に示される如く，第 1 編で既述の sex chromatin の最高数はX染色体の数より1を減じた数に相当すると の法則に合致した。

mosaic 型の $\mathrm{XO} / \mathrm{XY}$ 症例に sex chromatin が見ら れなかつたととはその性染色体構成より当然であるが， $\mathrm{XY} / \mathrm{XXY}$ 症例に見られなかつたととは次の様に考察し たい. 即ち mosaic の現われる形式には種々あり, 組織 単位で又同じ組織でもその部位により性染色体構成を異 にした細胞が混在することが考えられる．Jacobs ら (1961) ${ }^{50)}$ 血液では XO/XY 型, 皮虚では $\mathrm{XO}$ 型 であつた症例を 報告しているし, Mellman ら (1963) 115)注右腹部の皮㖇及び左性腺で XO/XY 型, 左腹部の 皮䖉及び右性腺で XO 型であつた症例を報告している. 又 Leon 万 (1961) ${ }^{116)}$ は当初骨能細胞にて検查して XXY 型と報告した症例 ${ }^{177}$ を再度末梢血液培養法によ り検查して XY/XXY 型の mosaic であつた症例を報 告している. 自験例も Leon 万(1961) ${ }^{116)}$ の症例と全 く同様で，最初骨䯣細胞15個を観察して XXY 型とし

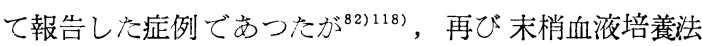
で検查した所，XY/XXY 型であることが判明した症例 である. この様に mosaic 型は種くの形式が存在する 故, 当然 sex chromatin も検査する部位によりその所 見を異にすることが考えられる。自験 XY/XXY 症例 では buccal smear で sex chromatin は $^{1} / 200 て ゙$, drumstick も $\% 500$, 及び数個所の皮膚の sex chromatin すべて陰性であつた．併し更に他の組織に打いて sex chromatin が見られる可能性を有していると考えられ る.

以上の mosaic 型についての考察より, 染色体検査を する際には可及的種々の組織について扢てなう必要があ り，かつ多くの細胞について観察される必要性が強調さ れる. 又 mosaic 定例では sex chromatin の出現頻度 が低くなることが知られているが103)，私は男で one Barr body, 女で two Barr bodies が $5 \%$ 以上涀ら れるときに再度 sex chromatin 検查を行い, 又同時 に染色体検査を行う様にしている.

iii。性染色体已性決定

自験 XXY, XXYY, XXXY, XXXXY 及び XY/XXY 型の21例及びこれらと同型の既報告例（高井ら，1964） 15)を観察するに, その性腺は全て幸丸であつたととは, $\mathrm{X}$ 染色体が $1 \sim 3$ 個と余剩に存在してもY染色体が 1 個 
存在すれば性腺原基の䯣質が発育して皮質の分化が抑制 され殬丸となることを意味し，Y染色体には強い男性決 定権の存在することが知れる.

しかしながら自験 XO/XY 症例では性腺が 1 側睪 丸，他側欠如（ヘルニアの手術の既往があるのでその 際, 剔除された可能性もある) であつたが同型の mosaic 症例法少くも22例の報告を見るが（高井ら，1964）, ${ }^{15)}$ その性腺治胎生期性腺, 箤丸, 卵巣又络 ovotestis と一 定性がなかつたことは，XO/XY 型の mosaic において

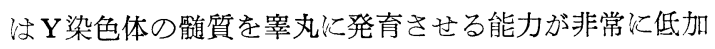

していることを示す。

又Y染色体を有しないで莘丸が観察された報告が見ら

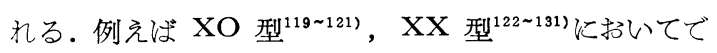
あるが, これらの症例の染色体検查は限られた材料のみ しか行われていない点より, 体組織のどこかにはY染色 体が疗在する可能性が十分に予想され, 更にY染色体の 一部がX染色体に転座して, それが微小片の転座のため 仅形態的に正常の XX 型と識別出来ない可能性などが 考えられる (Sohval, 1963 : 牧野, 1963). ${ }^{132) 133)}$ 実際, 前述の Jacobs ら (1961) ${ }^{50)}$ の症例は皮佣で XO型, 血 夜で XO/XY 型であつたし, 又 Solomon ら (1964) 以先に Oikawa ら (1961) ${ }^{127)}$ が報告したY染色体安有 しないで睪丸を持つた男の症例について血夜及び組織培 養にてY染色体を含む細胞核も見られる mosaic 型であ つたととを報告している. 又 Lamy ら (1962) ${ }^{135)}$ 住核 型46/XX の sex chromatin 陽性の男を報告して, Y 染 色体の転座がその核型分析で強く示唆され, 本症例の本 来の核型は $47 / \mathrm{XXY}$ であろろと述べている.いずれに せょ, これらの体汇関しては今後の研究に残された問題 である。

iv. 性染色体構成と性分化

a. 男の数的異常

Jost $(1953)^{136)}$ は動物実験で, 胎生初期䔂丸から hormone like morphogenic secretion があり, これが性 管, 外性器の分化に関与していると報告し, 島村 (19 $63)^{137}$ は人の胎生期殬丸代於いても同様の secretion が 存在する事に, ある程度の根拠を与える研究結果を報告 している.

自験20例に関すれ认゙副䔂丸, 精管を全例に認め, 又外 性器も全く正常の男性型を呈したととは, X染色体が 1 $\sim 3$ 本と余剩に存在する個体の胎生期宰丸淤いても, Müller 氏管の発育を完全に抑制しWolff 氏管を発育 させ, かつ外性器を男性分化させるに十分の morphog- enic secretion があるととを意味する.

しかしながら XXXXY 型の既報告21例に関すれば記 載のある18例中10例に停留幸丸が見られ，しかもそのう 56 例が両側性であつた (高井ら，1964). ${ }^{15)}$ 又陰莖及び 陰囊山殆んどの症例で発育不全を呈し, Fraccaro ら（19 60) ${ }^{18) 19)}$ の症例では陰囊 2 分化が見られている. Melicow ら (1964) ${ }^{138)}$ testicular morphogenic hormone 牥多分舎丸の降下を助力するものであろうと述べている が，乙の観点からすると XXXXY 型の個体ではその胎 生期睪丸の性分化機能がやや減弱していることになり， その原因は 3 個の過剩のX染色体の存在に帰せられるこ ととなる.XXXY 型の既報告例中記載のある5例につ いては, その性管系及び外性器の分化程度に異常を見て いない (高井ら，1964). ${ }^{15}$ 又自験 XXY 型 1 例停留 莘丸を見たが, De la Chapelle ら (1963) ${ }^{139)}$ も同様の 2 例を報告している. 更に Gray $(1961)^{140)}$ 及び Conen ら (1964) ${ }^{141)}$ 永道下裂を伴つた症例を報告している. この様に XXY 型の個体に停留睪丸又は尿道下裂が見ら れたことは, 偶然に合併したものか, 又は XXY 型の個 体注正常の XY 型の個体異常を多く伴うものである心は 現在の所判然とせず, 今後に残された間題と思われる.

以上浪X染色体の過剩に存在する個体に関してであつ たが, X染色体の過剩に関すれば自験 XXYY 型症例で 洁その内外性器の分化汇異常を認めず, 同型の既報告 14 例及び XXXYY 型の 1 例炕関しても同様の所見であつ たが, XYY 型の10例の報告学観察するに hypogonadism と記載されているものが 2 例, 停留等丸が 2 例及び尿道 下裂の 1 例を見るととは，Y染色体の過剩はある程度の 性分化異常を招く様に思われた (高井ら，1965). ${ }^{106)}$

b. 男の mosaic

自験 XY/XXY 型症例ははその内外性器は完全な男性 型を呈した．同型の既報告例で記載ある 6 例に関しても 同様であつた (高井ら, 1964$).{ }^{15}$ ) その他に両側の性腺が 殬丸で mosaic 型の報告は $\mathrm{XX} / \mathrm{XXY}^{142)}, \mathrm{XY} / \mathrm{XXXY}^{143)}$ ${ }^{144)}, \mathrm{XXY} / \mathrm{XXXY}^{145)}, \mathrm{XXXY} / \mathrm{XXXXY}{ }^{95) 146)}, \mathrm{XXXY} /$ $\mathrm{XXXXY} / \mathrm{XXXXXY}^{147)}$ 等を見るが, その内外性器法 男性型を呈したと記載されている.

しかしながら自験例 $\mathrm{XO} / \mathrm{XY}$ 型は性腺が 1 側等丸， 他側欠如であつたが，腟及び子宮を有し，又同型の $21 の$ 報告例中両側殬丸を有した 5 例関しても, 腟, 子宮 及び卵管が見られたととは ${ }^{15)}, \mathrm{XO} / \mathrm{XY}$ 型の鋅丸柱その 胎生初期に於いて testicular morphogenic hormone の 分泌機能が全くないものの様に思われる. しかし又, 女 
性性器を有し尿道下裂を呈する外陰部に性腺（胎生期性 腺，垶丸又は ovotestis）を触れた症例を 4 例に見ること $は^{15)}$, Melicow ら (1964) ${ }^{138}$ の testicular morphogenic hormone は箤丸降下機構に関与するであろろとの観 点からすると, 上述の 4 例の $\mathrm{XO} / \mathrm{XY}$ 型を胎生期金丸 は Müller 氏管の発育を抑制して Wolff 氏管を発育 させるに十分な同 hormone を分泌しないが，性腺を降 下させる程度の分泌㙨能があつたとも云える。しかしな がら, 莘丸降下機構の判明していない現在では, 全く憶 測の域を出ない事は言を俟ない。

\section{c. 女の数的異常}

自験 XXX 1 例では試騟開腹術を施行していないが， その内性器は患者が13才時より規則正しく月経を見てい るととより異常はないと思われる。 XXX 型の既報告45 例中月経に関して記載のある22例に関すれば16例が正常 飞月経を認めて抢り，更に妊娠の既往を有する女性は 6 例で夫々正常の子供 (男 9 各, 女 6 名) を出産している (高井ら，1964). ${ }^{15)}$ 又 XXXX 型は Carr ら $(1961)^{17)}$ の 2 例の報告を見るがいずれも外性器恃正常女性型で， 月経を正常に有している. 更に XXXXX 型の 2 才の 女性が Kesaree ら (1963) ${ }^{20)} に よ り$ 報告されているが, その外性器は正常女性型を呈し, 子宮を触れている。

以上泳女性でX染色体の過剩に存在する個体に関して であつたが，正常女性の XX 型より 1 個のX染色体の 少ないXO型の個体は gonodal dysgenesis, gonadal aplasia 又は ovarian agenesis と呼ばれる如く, その性腺 は卵巣の stromaに似た結合識よりなる索状物であるが, 表現型女性で正常女性外性器を呈し腟, 子宮及び卵管を 有することが知られている ${ }^{132133)}$. このととは XO 型 では性腺は分化せず，性腺無発生の状態に於いてもその 内外性器は女性を呈するととを意味し, Jost $(1953)^{136)}$ の性分化理論に合致する. 又上述の X 染色体を過剩汇 有する既報告例の全てが正常の女性内外性器を有した事 も Jost (1953) ${ }^{136)}$ の理論より当然のととである.

一方, 以上自験例及び既報告例を観察するに, 男で $\mathrm{X}$ 染色体が 1 〜 個と多く存在してもその内外性器分化に 関して殆んぞ影響を与えず，女で XXX 型の多くに， 又XXXX 型の 2 例に月経を正常に認めたととは, 第 1 編で既述した Ohno ら $(1961)^{24)}$ 及び Lyon (1961) ${ }^{35)}$ の説, 即ち過剩のX染色体は遺伝的, 機能的に不活性化 された状態にあるとの説によつて最もよく説明されるこ ととなる。

V. 性染色体構成異常々性腺の形熊及び機能

\section{a. 男の数的異常}

sex chromatin 陽性男性の思春期後に於ける臨床所見 の中で最も特異的なことは，精細管の萎縮确子化及び Leydig 細胞の著増を示す䔂丸組織像であることは多く の著者の報ずる所であり，特に Stewart ら $(1959)^{148)}$ はこの点を強調している. 自験例で, 思春期後期及び思 春期後と思われる14才以降の15例に関すれば上述と全く 同様の睪丸組織像を呈したが，思春期前又はその初期に 相当する己思われる11才及び12才の XXY 型の 2 例で は精上皮細胞が極度の減少を示す他は同年令の正常睪丸 像と異なる所がなく，又思春期の中期に相当すると考元 られる12〜13才の 3 例に関すれば殆んぞの精細管に执い てその基底膜の肥厚が見られ一部の精細管では完全に萎 縮硝子化を示し，思春期後に見られる特異的鬲見への移 行型を呈した. 又 FSH に関すれば11才及び12才のXX $\mathrm{Y}$ 型 2 例では輕度の上昇を示したのみであつたが，その 他の症例では 1 例を除いた全てが非常な高值を見た。

思春期前における sex chromatin 陽性の症例につい ては, Siebenmann ら (1958) ${ }^{149}$ は 11才の症例て精祖 細胞を正常の数に見たと述べているが，Conen ら（19 $64)^{141)}$ が 6 カ月の症例, Lawrenceら $(1961)^{150)}$ は10カ月 の症例, Mosier ら (1960) ${ }^{903}$ は 7 才の症例, 及び Ferguson-Smith (1959) ${ }^{85}$ は 7 才より12才の8 例について 夫々報告しているが，いずれも精上皮系細胞が全く見ら れないか又は見られても非常に乏しかつた他は正常例と 比較して特に 異常所見はなかつたと述べている。ただ Ferguson-Smith $(1959)^{85)}$ の報告例中12才の症例では精 細管の硝子様変性が一部に見られ又 FSH の高值が観察 されている.

以上より，X染色体を過剩に有する男の睪丸組織像に 共通する所見は，思春期前に招いては精上皮系細胞の極 度の減少であり，思春期後では精細管の萎縮硝子化及び Leydig 細胞の異常な増加と云える. この様な変性機構 の解釈としては，X染色体を過剩に有する個体ではその 思春期における androgen の分泌不全のためであろうと する説と, 又一方では個体又は組織によつて hormone の感受性が異なるであろろとの考えより，X染色体の数 的異常を示す患者では androgen の分泌があつても標的 㵴器の androgen-resistence のあるために上述の変性過 程をとるものであろろとする説がある.

前者の androgen の思春期に於ける分泌不全について は de la Balze ら (1952) ${ }^{1511} の$ 释丸の組織化学的研 究に基づく仮説がある。即ち思春期に於いては FSH は 
正常に分泌されているが, Leydig 細胞の正常発育が LH の久乏，LH の質的变化又は Leydig 細胞の LH に対 する感受性の低下などのために障害されて, Leydig 細 胞よりの androgen の分泌が久乏し，てのためにその正 常の形態及び機能を維持するに必要と考えられる精細管 壁の fibroblast 及び間質の結合織の增殖を招く，精細管 壁の肥厚は管内細胞が必要とする栄養素の到達を阻止 し, 精上皮細胞及び Sertoli 細胞は消滅する. 又 androgen 分泌不全は FSH の上昇安招くものであると仮定 した．更に彼らは精細管の正常発育には androgen 分泌する成熟した Leydig 細胞が管壁に接近して存在 するととが必要であろろと述べ, Klinefelter 氏症候群 の睪丸の一部にも正常の精子形成が認められたが，それ ら精細管の周囲には分泌機能を有した Leydig 細胞が見 られたと述べている。この仮説の観点から自験例を考察 するに，11才及び 12 才の 2 例に於いてはX染色体の過剩 存在により何らかの作用因子が Leydig 細胞の正常機能 を障害し, androgen の分泌不全を来たしたために FSH が軽度の上昇を示したが, 精細管の形態的な变化を認 めるには到らず, 思春期の極く初期における変性過程の 症例と思われる. 次いで12〜13才の 3 例については殆ん ぞの精細管にその管壁の肥厚が見られ又その一部が完全 に萎縮硝子化を示したことは丁度, 上記仮説と合致し, 思春期後に見られる特異的組織像への移行型と思われ た. 更に Klinefelter 氏症候群の梓丸組織の一部に精 上皮の完全な分化成熟を見たとの報告は数編あり ${ }^{54)}$, 自験にても 2 例に認めているが, 自験及び既報告 の思春期前の症例ですでに精上皮系細胞の著明の減少を 認めている事実より, de la Balze ら (1952) ${ }^{151)}$ の云 う成熟した Leydig 細胞の存在により, 管内細胞の栄養 が維持され正常の細管の形態及び機能を有するとする説 は不都合の様に思える.しかしながら自験例に於いて屢 マ Leydig 細胞の集塊に取り囲まれて精上皮系の細胞は あまり見られないが, 形態の比較的保持されている精細 管を見たととは de la Balze ら (1952) ${ }^{151)}$ の説を裏付 けるものの様にも思われた。

しかしながら上述の仮説は testicular-hypophyseal feed-back mechanism は Leydig 細胞にあるとの概念に 基づくものであるが，一方同機構は Leydig 細胞にあら ずしてその主役は精上皮であるとの概念がなされて揖 り, Johnsen (1964) ${ }^{155}$ は最近種くの性異常の患者を検 討して同機構は主に精上皮に inhibin が存在し, それ によつてなされるものであろうと述べている.この説に
よると, 自験11才及び12才の症例で FSH の上昇が先行 したのはその精上皮細細の著明な堿少に起因する事とな る.

又 Slaunwhite ら (1963) ${ }^{156)}$, 及び Giorgi ら (1963) ${ }^{157)}$ は androgen の低い事の他に標的藏器の hormone 感受性の低い事も起因するのであろろと述べているが， いずれにしても, X染色体の過剩に存在する個体の特異 的な殬丸の形態及び機能について適確な説明はなく，今 後の問題として研究される必要がある.

次に内外性器の発育を見るに自験に於いては前立腺は 殆えどの症例が発育不全を呈し, 精管は約半数に, 又耽 毛の発育不全を多く見たととは, てれら患者の思春期に 於ける androgen 分泌が低下していたことを示すものと 云える. Stewart 万(1959) ${ }^{148)}$ は 15例中 8 例に前立腺 の発育不全を見たと述べ，又恥毛炍関して Stewart ら $(1959)^{148}$ は 16例中 11例飞, Raboch (1964) ${ }^{158)}$ は 100例中22例にその発毛の不全を見たと報告している。 陰玍は自験に执いても, 又他の報告者に扔いても殆んぞ が正常を示すととは, 陰莖は androgen に非常に感受性 が高いことを意味するものの様である (Raboch, 1957) 157). 更に自験に於いて, 性生活の点に関しても androgen の分泌不全の結果を得たが，同様の報告は Raboch

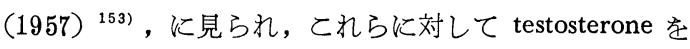
投与する事によつてある程度の正常化の期待がもたれ ている(148)152). 自験例にても testosterone 投与によつ て性慾の発現を見, 又恥毛の男性化を見た例がある（症 例13).との様汇臨床像を見るに sex chromatin 陽性の 男性は思春期及びそれ以後に於いて androgen 分泌の 低下があり, 又とれら個体はその睪丸の組織は別として androgen に感受性を有するものの様である.

いずれにせよ sex chromatin 陽性男子の臨床像は思 春期に抢ける androgen 分泌の低下, 標的臟器の androgen に対する 感受性及び思春期前に掞ける精上皮細胞 の極度の減少なぞが関係し, 複雑な過程をとるものの様 である。

次いで自験に打いて XXYY, XXXY 及び XXXXY 型の睪丸組織像及び尿中ホルモン測定值は $\mathrm{XXY}$ 型と 殆えぞ異つていなかつたととは男性に打けるX染色体の 数的異常の臨床像は XXY 型が基本となつている事を意 味し, 更に XYY 型が既述の如くある程度の性分化異常 を招くと考えられた事ょり，正常の䔂丸の形態及び機能 を発育させるに必要な性染色体構成は XY 型であると云 える. 又とのととは sex chromatin を形成するX染色 
体恃その全体に执いて遺伝的，及び機能的に不活性化さ れているとする Ohno ら (1961） ${ }^{24)}$ の説性不都合に思

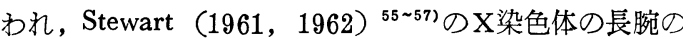
みが不活性化されるのであるうとする説を支持するもの と考えられる。

b. 男の mosaic

自験 XY/XXY 症例は Leydig 細胞を認めず, 又 FSH が低値を示し, 男に打けるX染色体の数的異常の臨床像 とは全く異つた。 Barr ろ $(1959 ， 1962)^{143) 144)}$ は XY $\mathrm{XXXY}$ 型の症例で知能低下及び two Barr bodies を認 めた他怯正常男子と全く異なる所がなかつたと報告して 扣り, 又 Paulsen 万(1964) ${ }^{159}$ 快 XY/XXY 症例で 正常の等丸組織像を呈したと述べているが，乙の様に mosaic 型ではその成因からしても種々の臨床像をとる 事㹜予想される。

c. 女の数的異常

$\mathrm{XXX}$ 型では 6 例(そのうち 2 例は XXX-18 trisomy) に卵巣の組織検査がなされており，5例に原始卵胞の 著しい減少又は卵胞形成不全が見られているが, 先述 の如く記載ある22例中17例が正常の月経を認め， 6 例が 妊娠の既往を有したととは，その性腺の形態的又機能的 な不全はないものの様に思える ${ }^{15)}$. 又尿中ホルモン測定 む5 例に施行されているが FSH の高值を示した 1 例を 除け特に異常を認めていない ${ }^{15)}$. XXXX 型の 2 例17) についても月経を有し，尿中ホルモン測定値に特に異常 を認めていないととはこれら性腺も活ざ正常と予想され る.

一方 XO 型はその性腺の分化を殆んど見ない事実よ り，女性で正常の性腺が発育するためには 2 個のX染色 体が必要であるものの様である．X染色体の長腕が 2 個 接合して出来たと考えられる iso-X 染色体と正常のX染 色体よりなる個体は one Barr body を有し臨床像は XO 型と全く同じであるここが知られている ${ }^{47 \sim 51)}$. このとと より, 正常な卵巣の発育にはX染色体の短腕が 2 個以上 存在するととが 必要であろうと考えられている ${ }^{132) 133)}$.

vi. 性染色体構成異常の生殖器系以外の器管に及ぼす 影響

\section{a. 男}

知能指数に関すれば，第 4 編の研究で発見された症例 を除いた XXY 型10例中 5 例が90未満であつた。 又自験 $\mathrm{XXXY}$ 及び XXXXY 症例のそれは 36 及び 30 と著明な 低下を示し，X染色体が過㮃となればなる添ど精薄の程 度が強くなる事を示す．との事は他の報告例に掞いても
同様であつた（高井ら，1964） ${ }^{15)}$.

女性型乳房症は自験 15 才以上の症例に関しては ${ }^{3 / 13}$ (23\%)に見られたが，Stewart ら (1959) $\left.{ }^{148}\right) / 2{ }^{10} / 16, \mathrm{Ra}$ boch (1964) ${ }^{158}$ 汇 ${ }^{25} / 100$, Mosier ら (1960) ${ }^{901}$ は $/ 9$ 及 び de la Chapelle ら (1963) ${ }^{1399}$ は $4 / 8$ に見たと述べて いる. 又女性型乳房と尿中 estrogen 值の関係について

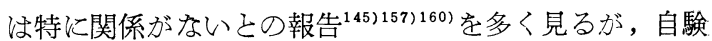
に於いても同様で estrogen を測定した10例中 7 例が高 值を示したが，そのうちで女性型乳房を呈したものは 1 例のみであつた.この点については Giorgi ら (1963) ${ }^{157\rangle}$ はホルモンの感受性が組織により異なるためであろうと している.

自験 XXYY 症例では第 5 指の弯指症を見たが, 自験 例を含めY染色体の過剩に存在した既報告26例について 見ると内反尖足, 春椎側弯症及び先端巨大症等の骨成熟 の異常を示したものが10例に，又血管皮膚系の異常が 6 例に見られた（高井ら，1965） ${ }^{106)}$.

自験 XXXXY 症例では橈尺骨癒合，第 5 指の弯指 症，両眼隔離症，内㫮鳌皮及び斜視を見たが，同型の既 報告20例中約半数に自験例に於けると同様の所見が見ら れた(高井ら，1964） ${ }^{15)}$.

以上ょり男性に於ける性染色体の過剩に存在する個体 では知能の低下, 女性型乳房の出現, 骨格系の異常, 眼 科的異常及び皮唐血管系の異常をもたらす傾向が考えら れる。

\section{b. 女}

XXX 型では知能指数が自験例を含めて記載ある27例 全てが低下を示している（高井ら，1964） ${ }^{15)}$.

XXXX型 2 例のそれは 30 及び50 報告されて抢り ${ }^{17)}$, 男性に於けると同様に XXX 型よりも更に知能低下が 増す傾向が見られる。しかしながら女性に於けるX染色 体の過剩は知能指数の低下を除けば男性に於ける様な性 器以外の器管の異常を殆んぞ見ない.

\section{4. 結 語}

1).性染色体構成異常を呈した 23 例について, 臨床 的, 細胞学的及び性腺の組織学的並び沉内分泌学的所見 を研究した.

2). 患者出生時の母親の年令が一般大衆のそれより約 5 年高令であつたことは, 性染色体構成異常の成因と関 係がある様に思えた。

3). sex chromatin の所見々性染色体構成との関係虽 第 1 編で既述の sex chromatin の単一X染色体説を满 足した.とのととは sex chromatin 検査法の臨床的価 
值に実証的確認を与えるものであるが， mosaic 型及び Y染色体の過剩を知るには更に染色体検査が必要であ り, 可及的染色体検查む施行されなりればならないと思 われた。

4). Y染色体には強 い性決定権の存在する事が知れ た. XO/XY 型はこの例外であつた. 又性分化に関すれ 㭷でX染色体が 1 ～個と過剩に存在しても, その胎 生期宰丸性管及び外性器を男性分化させるに十分の機 能のあることが知れた.しかしながら文献を考察して， 3 個の過剩のX染色体を有する個体及びY染色体を過剩 に有する個体の胎生期辩丸はや〉その性分化能力が減弱 するものの様であつた. 又女でX染色体の過剩の存在流 その性腺の形態及び機能に左程の影響を与えないものの 様に思われた。

5). 男の性染色体構成異常症例に於ける思春期後の特 異的な臨床像はその睪丸組織像であつた。 XXYY，XX $\mathrm{XY}$ 及び XXXXY 型のそれも殆んぞ XXY 型と異なる 所がなかつた. 思春期前に於ける症例に共通の所見注精 上皮細胞の極度の減少であつた. これが思春期後の精細 管の萎縮硝子化及び Leydig 細胞の異常な増加との特異 的な組織像に導く機序は, 思春期に於ける androgen の 分泌不全及び androgen に対する標的臟器の感受性の低 下なぞが考えられた。

6).性染色体構成異常は性器以外, 特に知能の発達及 び骨成熟の異常等をもたらすととが知れた。 又文献を考 察してY染色体にも常染色体由来の遣伝因子が存在する ものの様に思われた。

7).性染色体構成異常症例の臨床像を考察して, sex chromatin を形成するX染色体はその全体が遺伝的及び 機能的に不活性化されているとは思われなかつた.

\section{全編の結論}

1. sex chromatin 検查が一般臨床検查法として用い られるには, まずその染色方法が簡便でしかも sex chromatin が判然と観察可能であるととが要求され, 同時 に sex chromatin の判定規準を定めなければならない.

i）私は Guard 氏法, Feulgen 法, aceto-orcein 法, Giemsa 法及び hematoxylin and eosin 法を正常例茨 び性染色体構成異常例に施行して比較検討したととろ, aceto-orcein 法が上述の点で最も適した染色法であるこ とを知つた。

ii）正常男女各 100 例及び性染色体構成異常18例々つ いて異質染色質塊の核内位置別出現頻度を検討して, sex chromatin は核膜に接する大きさ $1 \mu$ 内外の異質染色
質のみとすべきであるとの見解を得た。

2. 本邦では精薄児群に打ける sex chromatin 異常 者の頻度及び sex chromatin と性染色体構成との関係 についての詳細な報告はいまだ見ない。

i）私は北海道の精薄児 1,198 名（男 683 名，女 515 名）に sex chromatin 検査を施行して男 13 名及び女 2 名の sex chromatin 異常者を発見した. 男の異常者頻 度 $1.90 \%$ は欧米の諸家の平均頻度に比して約 2 倍の高值 に相当するものであつた。

ii）発見した異常例について染色体検査を施行した が, その性染色体構成は sex chromatin の所見より十 分に推測可能であつた。 とのととは screening method としての sex chromatin 検査法の意義に確証を与える ものであつた.な抬近年 sex chromatin の最高数はX 染色体の数より1を減じた数に等しいとの説が Ohno 又は Lyon 等により提唱されているが，自験性染色体構 成異常症例の sex chromatin の所見は上記の説心実証 的裏付けを与えるものであつた.

本論文の要旨は第 4,5 回日本先天異常学会総会, 第 169，172回日本泌尿器科学会北海道地方会, 並びに第 18回北海道ホルモン同好会で発表した。な扰本研究は昭 和39年度文部省科学研究費の援助による).

稿を終えるにあたり終始御懇篤なる御指導並びに御校 閲を賜つた恩師高井修道教授に农心より感謝の意を表し ます．又精薄児童の検査に対して御協力をいただいた関 倸者の方々，染色体分析をしていただいた北海道大学理 学部牧野教室の方々並びに当教室の方々に対し深く感謝 致します。

\section{交献}

1) Barr, M.L., and Bertram, E.G.: Nature, 163, $676,1949$.

2) Barr, M.L., Bertram, L.F., and Lindasy, H. A.: Anat. Rec., 107, 283, 1950.

3) Barr, M.L.: Exp. Cell Res., 2, 288, 1951.

4) Graham, M.A., and Barr, M.L.: Anat. Rec., 112, 709, 1952.

5) Moore, K.L., and Barr, M.L.: J. Comp. Neurol., 98, 213, 1953.

6) Moore, K.L., Graham, M.A., and Barr, M. L.: Surg. Gynec. Obstet., 96, 641, 1953.

7) Moore, K.L., and Barr, M.L.: Acta Anat., 21, 197, 1954.

8) Moore, K.L., and Barr, M.L.: Lancet, 2, $57,1955$.

9) Klinger, H.P.: Acta Anat., 30, 371, 1957.

10) Klinger, H.P.: Exp. Cell Res., 14, 207, 1958. 
11) Grumbach, M.M., Morishima, A., and Chu, E.H.Y.: Acta Endocrinol., 35 (Suppl. 51), $633,1960$.

12) Grumbach, M.M., and Morishima, A.: Acta Cytolog., 6, 46, 1962.

13) De la Chapelle, A.: Acta Endocrinol., 40 (Suppl. 65), 1962.

14) Jacobs, P.A., Baikie, A.G., Court Brown, W. M., MacGregor, T.N., Maclean, N., andHarnden, D.G.: $\quad$ Lancet, 2, 423, 1959.

15）高井修道, 森田茂豊, 島村昭吾, 疋田政博 : 札 幌医誌, 26, 184, 1960.

16) Ferguson-Smith, M-A., Johnston, A.W., and Handmaker, S.D.: Lancet, 2, 184, 1960.

17) Carr, D.H., Barr, M.L., and Plunkett, E.R.: Can. Med. Assoc. J., 84, 131, 1961.

18) Fraccaro, M., Kaijser, K., and Lindsten, J.: Lancet, 2, 899, 1960.

19) Froccaro, M., and Lindsten, J.: Lancet, 2, 1303, 1960.

20) Kesaree, N., and Woolley, P.V.: J. Ped., 63, 1099, 1963.

21) Böök, J.A., and Santesson, B.: Lancet, 1, $859,1960$.

22) Böök, J.A., and Santesson, B.: Lancet, 2, $318,1961$.

23) Ohno, S., Kaplan, W.D., and Kinosita, R.: Exp. Cell Res., 18, 415, 1959.

24) Ohno, S., and Makino, S.: Lancet, 1, 78, 1961.

25) Kosin, I.L., and Ishizaki, H.: Science, 130, 43, 1959.

26) Lima-De-Faria, A.: J.B.B.C., 6, 457, 1959.

27) Taylor, J.H.: J.B.B.C., 7, 455, 1960.

28) Morishima, A., Grumbach, M.M., and Taylor, J.H.: Proc. Nat. Acad. Sci., 48, 756, 1962.

29) German, J.L., III.: Lancet, 1, 744, 1962.

30) Giannelli, F.: Lancet, 1, 863, 1963.

31) Rowley, J., Muldal, S., Gilbert, C.W., Lajtha, L.G., Lindsten, J., Fraccaro, M., and Kaijser, K.: Nature, 197, 251, 1963.

32) Atkins, L., Böök, J.A., Gustavson, K.H., Hansson, O., and Hjelm, M.: Cytogenetics, 2, 208, 1963.

33）大野乾：綜合医学, 21, 79, 1964.

34) Davidson, R.G.: J. Ped., 65, 765, 1964.

35) Lyon, M.F.: Nature, 190, 372, 1961.

36) Ohno, S., and Hauschka, T.S.: Cancer Res., 20, 541, 1960.

37) McKusick, V.A.: Ann. Int. Med., 56, 991, 1962.
38) Lyon, M.F.: Am. J. Human Genet., 14, $135,1962$.

39) Beutler, E., Yeh, M., and Fairbanks, V.F.: Proc. Nat. Acad. Sc., 48, 9, 1962.

40) Davidson, R.G., Nitowsky, H.M., and Childs, B.: Proc. Nat. Acad. Sc., 50, 481, 1963.

41) Beutler, E., and Baluda, M.: Lancet, 1, 189, 1964.

42) Emery, A.H.: Lancet, 1, 1126, 1963.

43) Pearson, C.M., Fowler, W.M., and Wright, S.W.: Proc. Nat. Acad. Sc., 50, 24, 1963.

44) Mann, J.D., Cahan, A., Gelb, A.G., Fisher, N., Hamper, J., Tippett, P., Sanger, R, and Race, R.R.: Lancet, 1, 8, 1962.

45) Gorman, J.G., Di Re, J., Treacy, A.M., and Cahan, A.: J. Lab. \& Clin. Med., 61, 642, 1963.

46) Reed, T.E., Simpson, N., and Chown, B.: Lancet, 2, 467, 1963.

47) Fraccaro, M., Ikkos, D., Lindsten, J., Luft, R., and Kaijser, K.: $\quad$ Lancet, 2, 1144, 1960.

48) Blank, C.E., Gordon, R.R., and Bishop, A.: Lancet, 1, 947, 1961.

49) Lindsten, J.: Lancet, 1, 1228, 1961.

50) Jacobs, P.A., Harnden, D.G., Buckton, K.E., Court Brown, W.M., King, M.J., McBride, J.A., MacGregor, T.N., and Maclean, N.: Lancet, 1, 1183, 1961.

51) Hamerton, J.L., Jagiello, G.M., and Kirman, B.H.: Brit. Med. J., 1, 220, 1962.

52) Muldal, S., Gilbert, C.W., Lajtha, L.G., Lindsten, J., Rowley, J., and Fraccaro, M.: Lancet, 1, 861, 1963.

53) Sparkes, R.S., and Motulsky, A.G.: Lancet, 1, 947, 1963.

54) Gartler,S.M., and Sparkes, R.S.: Lancet, 2, 411, 1963.

55) Stewart, J.S.S.: $\quad$ Lancet, 2, 104, 1961.

56) Stewart, J.S.S.: Lancet, 2, 317, 1961.

57) Stewart, J.S.S.: Lancet, 2, 1269, 1962.

58) Guard, H.R.: Amer. J. Clin. Path., 32, 145, 1959.

59) 中川完二 : 逓信医学, 13, 1, 1961.

60）金井三郎：日泌尿会誌, 49, 187, 1958.

61) Sanderson, A.R., and Stewart, J.S.S.: Brit. Med. J., 2, 1065, 1961.

62) Lennox, B.: Stain Technol., 31, 167, 1956.

63) Eskelund, V.: Acta endocr., 23, 246, 1956.

64) Greenblatt, R.B., and Manautou, J.M.: Am. J. Obst. \& Gynec., 74, 629, 1957.

65) Klinger, H.P., and Ludwig, K.S.: Stain Technol., 32, 235, 1957. 
66）熊切俊太郎：臨婦産, 10, 741, 1956.

67）佐藤英吾，片山健：派信医学, 9, 172, 1957.

68）安達正純：産婦の世界, 9, 528, 1957.

$69)$ 落合京一郎：最新医学, 13, 1751, 1958.

70）黒川膠：日産婦誌, 10, 1575, 1958.

71）安藤畫一：産と婦, 23, 407, 1956.

72）坚玉正道：日不妊会誌，3,162, 1958 .

73）鈴木雅洲, 天野保二：日医新報， 1678, 19, 1956.

74）松永武三：日不妊会誌，6, 138, 1961.

75) Thiriez, H.: 79) ょり引用.

76）鈴木雅洲，矢島高明：産婦人科の実際， 5,518 , 1956.

77）松永武三, 古山順一：日不妊会誌, 10, 91, 1965.

78) Marberger, E., Boccabella, R.A., and Nelson, W.O.: Proc. Soc. Exper. Biol. \& Metab., $89,488,1955$.

79) Barr, M.L.: in Intersexuality (edited by Overzier, C. ), p48, London, 1963.

80) Moorhead, P.S., Nowell, P.C., Mellman, W. J., Battips, D.M., and Hungerford, D.A.: Exp. Cell Res., 20, 613, 1960.

81) Pasqualini, R.Q., Vidal, G., and Bur, G.E.: Lancet, 2, 164, 1957.

82）高井修道: 日医新報，1957，21，1961.

83) Ferguson-Smith, M.A.: Lancet, 1, 928, 1958.

84) Prader, A., Schneider, J., Francés, J.M., and Züblin, W.: Lancet, 1, 968, 1958.

85) Ferguson-Smith, M.A.: Lancet. 1, 219, 1959.

86) Barr, M.L., Shaver, E.L., Carr, D.H., Plunkett, E.R.: J. Ment. Def. Res., 4, 89, 1960.

87) Cornwell, J.G.: 94）ょり引用.

88) De la Chapelle, A., and Hortling, H.: Nord. Med., 63, 256, 1960.

89) Ferguson-Smith, M.A.: 94) より引用.

90) Mosier, H.D., Scott, L.W., and Cotter, L.H.: Pediatrics, 25, 291, 1960.

91) Shapiro, A., and Ridler, M.A.C.: J. Ment. Def. Res., 4, 48, 1960.

92) Breakey, W.R.: J. Anat., 95, 618, 1961.

93) Carr, D.H., Barr, M.L., and Plunkett, E.R.: Can. Med. Assoc. J., 84, 873, 1961.

94) Israelsohn, W.J., and Taylor, A.I.: Brit. Med. J., 1, 633, 1961.

95) Maclean, N., Mitchill, J.M., Harnden, D.G., Williams, J., Jacobs, P.A., Buckton, K.A., Baikie, A.G., Court Brown, W.M., McBride, J.A., Strong, J.A., Close, H.G., and Jones, D.C.: Lancet, 1, 293, 1962.

96) Fraser, J.H., Campbell, J., MacGillivray, R. C.. Boyd, E., and Lennox, B.: Lancet, 2, $626,1960$.

97) Johnston, A.W., Ferguson-Smith, M.A., Han- dmaker, S.D., Jones, H.W., and Jones, G.S.: Brit. Med. J., 2, 1046, 1961.

98) Breg, W.R., Cornwell, J.G., and Miller, O. J.: Am. J. Dis. Child., 104, 534, 1962.

99) Day R.W., Larson, W., and Wright, S.W.: J. Ped., 64, 24, 1964.

100) Moore, K.L.: $\quad$ Lancet, 1, 217, 1959.

101) Bergemann, E.: Schweiz. Med. Wschr., 10, 292, 1961.

102) Maclean, N., Harnden, D.G., and Court Brown, W.M.: Lancet, 2, 406, 1961.

103) Maclean, N., Harnden, D.G., Court Brown, W.M., Bond, J., Mantle, D.J.: Lancet, 1, $286,1964$.

104) Jacobs, P.A., and Strong, J.A.: Nature, 183, 302, 1959.

105) Takai, S., Morita, T., Shimamura, S., and Tonomura, A.: J. Urol., 88, 533, 1962.

106）高井修道, 佐々木恒臣, 疋田政博: 日泌尿会誌, $56,616,1965$.

107) Takagi, N., Makino, S., Takai, S., and Hikita, M.: Proc. Jap. Acad., 41, 175, 1965.

108) Ford,C.E., Jacobs, P.A., and Lajtha, L.G.: Nature, 181, 1565, 1958.

109）松島早苗：木と臨， 10, 169, 1962.

110）神戸川明：昭和医誌, 20（6 ), 1, 1960.

111）神戸川明：木と臨，11，189, 1963.

112) 神戸川明：日本内分泌誌，38, 807, 1961.

113) Penrose, L.S.: Ferguson-Smith, M.A., A.M. A. Arch. Int. Med., 105, 627, 1960. より引用.

114) Ferguson-Smith, M.A., Mack, W.S., Ellis, P. A., Dickson, M, Sanger, R., and Race, R.R.: Lancet, 1, 46, 1964.

115) Mellman, W.J., Klevit, H.D., Yakovac, W. C., Moorhead, P.S., and Saksela, E.: J. Clin. Endocrinol. Metab., 23, 1090, 1963.

116) Leon, N., Epps, D.R., Beçak, M.L., and Beçak, W.: Lancet, 2, 880, 1961.

117) Leon, N., Ferrari, I., and Bottura, C.: Lancet, 2, 319, 1960.

118) Makino, S., Tonomura, A., Takai, S., and Matsunaga, E.: Proc. Jap. Acad., 36, 664, 1960.

119) Bloise, W., De Assis, L.M., Bottura, C., Ferrari, I.: Lancet, 2, 1059, 1960.

120) Atkins, L., and Engel, E.: Lancet, 2, 20, 1962.

121) Bottura, C., and Ferrari, I.: Brit. Med. J., 2, 1100, 1962.

122) Harnden, D.G., and Armstrong, C.N.: Brit. Med. J., 2, 1287, 1959.

123) De Assis, L.M., Epps, D.R., and Bottura, C.: 
Lancet, 2, 129, 1960.

124) Ferguson-Smith, M.A., Johnston, A.W., and Weinberg, A.: Lancet, 2, 126, 1960.

125) Hungerfold, D.A., Donnelly, A.G., Nowell, P.C., and Beck, S.: Am. J. Human Genet., 11, 215, 1959.

126) Gordon, R.R., O'Gorman, F.J.P., Dewhurst, C.J., and Blank C.E.: Lancet, 2, 736, 1960.

127) Oikawa, K., and Blizzard, R.M.: New Engl. J. Med., 264, 1009, 1961.

128) Shah, P.N., Naik, S.N., Mahajon, D.K., Pay master, J.C., Dave, M.J., and Tiwari, R.: J. Clin. Endocrinol. Metab., 21, 727, 1961.

129) Miller, O.J.: Fertility \& Sterility, 13, 93, 1962.

130) Bregman, R.U., Bregman, E.T., Cushner, G. B., and Woods, F.M.: J. Urol., 89, 475, 1963.

131) de la Chapelle, A., Hortling, H., Niemi, M., and Wennström, J.: Acta Med. Scand., 175 (suppl. 412), 25, 1964.

132) Sohval, A.R.: Physiol. Rev., 43, 306, 1963.

133）牧野佐二郎：人類の染色体, 紀伊国屋書店, 1963.

134) Solomon, I.L., Hamm, C.W., and Green, O. C.: New Engl. J. Med., 271, 586, 1964.

135) Lamy, M., De Glouchy, J., Frezal, J., Josso, N., and Feintuch, G.: 132) より引用.

136) Jost, A.: Recent Prog. Hormone Res., 8, $379,1953$.

137）島村昭吾 : 札幌医誌, 24, 150, 1963.

138) Melicow, M.M., and Uson, A.C.: J. Urol., 91, 402, 1964 .

139) De la Chapelle, A., and Hortling, H.: Acta endocri, 44, 165, 1963.

140) Gray, J.: Lancet, 1, 722, 1961.

141) Conen, P.E., Erkman, B., and Jeffs, R.D.: J. Urol., 91, 595, 1964.

142) Ford, C.E., Polani, P.E., Brighs, J.H., and Bishop, P.M.F.: Nature, 183, 1030, 1959.

143) Barr, M.L., Shaver, E.L., Carr, D.H., and Plunkett, E.R.: J. Ment. Def. Res., 3, 78,
1959.

144) Barr, M.L., Carr, D.H., Morishima, A., and Grumbach, M.M.: J. Ment. Def. Res., 6, 65, 1962.

145) Crawfurd, M. d'A.: Ann. hum. Genet., 25, $153,1961$.

146) Lamy, M., Aussannaire, M., de Grouchy, J., and Lalande, J.: Sem. Hôp., Ann. Péd., 39, $167,1963$.

147) Anders, G., Prader, A., Hauschteck, E., Schärer, K., Siebenmann, R.E., and Heller, R.: Helv. Poediat. Acta, 15, 515, 1960.

148) Stewart, J.S.S., Mack, W.S., Govan, A.D.T., Ferguson-Smith, M.A., and Lennox, B.: Quort. J. Med., 28, 561, 1959.

149) Siebenmann, R. and Prader, A.: Schweiz. Med. Wshr., 88, 607, 1958.

150) Lawrence, R., and Yuceoglu, A.M.: Am. J. Dis. Child., 101, 635, 1961.

151) De la Balze, F.A., Arrillaga, F.C., Irazu, J., and Mancini, R.E.: J. Clin. Endocrinol. \& Metab., 12, 1426, 1952.

152) Bunge, R.G., and Bradbury, J.T.: J. Urol., 76, 758, 1956.

153) Raboch, J.: J. Clın. Endocr., 17, 1429, 1957.

154) Raboch, J. and Bleha, O.: Endokrinologie, 39, 203, 1960.

155) Johnsen, S.G.: Acta endocr., Suppl. 90, 99, 1964.

156) Slaunwhite, W.R., Staubits, W.J., Jackson, J.F., and Koepf, G.F.: J. Clin. Endocrinol. \& Metab., 22, 989, 1963.

157) Giorgi, E.P., and Sommerville, I.F.: J. Clin. Endocrinol. \& Metab., 23, 197, 1963.

158) Raboch, J.: Fertility \& Sterility, 15, 331, 1964.

159) Paulsen, C.A., de Souza, A., Yoshizumi, T., and Lewis, B.M.: J. Clin. Endocrinol. \& Metab., 24, 1182, 1964.

160) Nelson, W.O., and Heller, C.G.: J. Clin. Endocrinol. \& Metab., 5, 13, 1945.

（昭和 40 年11月 17 日受付） 